\title{
Acute Suppressive and Long-Term Phase Modulation Actions of Orexin on the Mammalian Circadian Clock
}

\author{
Mino D.C. Belle, ${ }^{1}$ Alun T.L. Hughes, ${ }^{1}$ David A. Bechtold, ${ }^{1}$ Peter Cunningham, ${ }^{1}$ Massimo Pierucci, ${ }^{1}$ Denis Burdakov, ${ }^{2}$ \\ and Hugh D. Piggins ${ }^{1}$ \\ ${ }^{1}$ Faculty of Life Sciences, University of Manchester, Manchester M13 9PT, United Kingdom and '2King's College London and MRC National Institute for \\ Medical Research, London NW7 1AA, United Kingdom
}

Circadian and homeostatic neural circuits organize the temporal architecture of physiology and behavior, but knowledge of their interactions is imperfect. For example, neurons containing the neuropeptide orexin homeostatically control arousal and appetitive states, while neurons in the suprachiasmatic nuclei (SCN) function as the brain's master circadian clock. The SCN regulates orexin neurons so that they are much more active during the circadian night than the circadian day, but it is unclear whether the orexin neurons reciprocally regulate the $S C N$ clock. Here we show both orexinergic innervation and expression of genes encoding orexin receptors $\left(\mathrm{OX}_{1}\right.$ and $\left.\mathrm{OX}_{2}\right)$ in the mouse $\mathrm{SCN}$, with $\mathrm{OX}_{1}$ being upregulated at dusk. Remarkably, we find through in vitro physiological recordings that orexin predominantly suppresses mouse SCN Period1 (Per1)-EGFP-expressing clock cells. The mechanisms underpinning these suppressions vary across the circadian cycle, from presynaptic modulation of inhibitory GABAergic signaling during the day to directly activating leak $\mathrm{K}^{+}$ currents at night. Orexin also augments the SCN clock-resetting effects of neuropeptide Y (NPY), another neurochemical correlate of arousal, and potentiates NPY's inhibition of SCN Per1-EGFP cells. These results build on emerging literature that challenge the widely held view that orexin signaling is exclusively excitatory and suggest new mechanisms for avoiding conflicts between circadian clock signals and homeostatic cues in the brain.

Key words: arousal; circadian; electrophysiology; GABA; orexin A; suprachiasmatic

\section{Introduction}

Temporal organization of behavioral and metabolic states arises from the integrated activities of circadian and homeostatic neural networks. For example, key circuits involved in setting patterns of sleep and arousal include orexin/hypocretin (orexin A and B) neurons in the tuberal hypothalamus, and circadian clock neurons of the suprachiasmatic nuclei $(\mathrm{SCN})$. Within the SCN, the molecular circadian clock (of which the Period1-2 genes are key components) drives daily rhythms in electrical activity, with rhythmic SCN neurons being maximally active during the circadian day and minimally active across the circadian night (Ikeda, 2004; Brown and Piggins, 2007). Such pronounced day-night variation in a neuronal state allows the SCN to communicate temporal information to the rest of the brain and body. In nocturnal rodents, SCN output

\footnotetext{
Received Aug. 8, 2013; revised Jan. 27, 2014; accepted Jan. 29, 2014.

Author contributions: M.D.C.B., A.T.L.H., D.A.B., and H.D.P. designed research; M.D.C.B., A.T.L.H., P.C., and M.P. performed research; M.D.C.B., D.A.B., P.C., and H.D.P. analyzed data; M.D.C.B., D.A.B., D.B., and H.D.P. wrote the paper.

We thank the BBSRC and the Wellcome Trust for project grant funding to H.D.P. and D.B. We thank Rayna Samuels for technical assistance and Dr. Benjamin Boutrel for prepro-orexin knock-out mouse brains.

The authors declare no competing financial interests.

This article is freely available online through the J Neurosci Author Open Choice option.

Correspondence should be addressed to Dr. Hugh Piggins, Faculty of Life Sciences, 2.016 AV Hill Building, University of Manchester, Manchester M13 9PT, UK. E-mail: hugh.d.piggins@manchester.ac.uk.

DOI:10.1523/JNEUROSCI.3388-13.2014

Copyright $\odot 2014$ Belle et al.

This is an Open Access article distributed under the terms of the Creative Commons Attribution License (http://creativecommons.org/licenses/by/3.0), which permits unrestricted use, distribution and reproduction in any medium provided that the original work is properly attributed.
}

signals directly and/or indirectly suppress neural centers controlling motor activity and arousal during the day (Li et al., 2012). Indeed, the activity of the orexin neurons whose activation and suppression plays critical roles in the timing of arousal and sleep states (Chemelli et al., 1999; Tsunematsu et al., 2011) is under SCN circadian control (Zhang et al., 2004). In rats and mice, orexin neuronal activity (Estabrooke et al., 2001; Marston et al., 2008) and orexin release are most prevalent throughout their behaviorally active circadian night (Deboer et al., 2004).

Intriguingly the phase of the SCN circadian clock is also sensitive to feedback from arousal stimuli, particularly during the circadian day (Mistlberger and Antle, 2011; Hughes and Piggins, 2012). Such stimuli can recruit neuropeptide Y (NPY)containing neurons of the intergeniculate leaflet (IGL), which project to the SCN via the geniculohypothalamic tract (GHT; Harrington, 1997). NPY released from the GHT suppresses SCN neuronal activity (Gribkoff et al., 1998), inhibits clock gene expression in the SCN (Maywood et al., 2002), and in doing so shifts the phase and output of the clock. During the day, orexin neurons are also activated by such arousal-promoting stimuli (Estabrooke et al., 2001; Marston et al., 2008; Webb et al., 2008). Given that orexin-synthesizing neurons project widely throughout the brain (Peyron et al., 1998; Nambu et al., 1999), including structures of the neural circadian system (Bäckberg et al., 2002), orexin released during states of arousal may also influence SCN cellular activity. However, this raises an interesting paradox because activation of brain orexin receptors is generally considered excit- 
atory (Kukkonen, 2013) and yet SCN neuronal activity is low across the circadian night when orexin neuronal excitability and release in nocturnal rodents are maximal.

Here, we demonstrate that unlike its typical excitatory actions in the brain, orexin A (OXA) acts within the SCN to primarily suppress cellular activity, and that the mechanisms underlying neuronal suppression differ across the circadian cycle. In addition, we demonstrate that OXA application does not itself shift the phase of the clockwork, but instead orexin can enhance the actions of NPY on SCN clock cells. These results indicate that the output of the master circadian pacemaker is modulated by homeostatic circuits involved in arousal and energy balance in a manner that allows acute adaptation to changes in the internal and external environments.

\section{Materials and Methods}

\section{Animals}

For calcium imaging, electrophysiological, PCR, and immunohistochemical investigations, this study used male and female mice [ 8 weeks to 6 months old) hemizygous for the Period1::d2EGFP transgene (Per1EGFP-expressing mice in which an enhanced destabilized green fluorescent protein (EGFP) reports the activity of the Perl promoter; a gift from Professor D. McMahon, Vanderbilt University; Kuhlman et al., 2000)]. For luminometric assessment of the actions of orexin on the phase of the molecular circadian clock, adult (8 weeks to 6 months) male mPeriod2Luc knockin mice (PER2::LUC, a fusion protein of PERIOD2 and firefly luciferase (LUC; Yoo et al., 2004) were used. For additional immunohistochemical controls, we also used brain tissue from four mice lacking complete expression of the orexin gene (prepro-orexin knock-out mice; Chemelli et al., 1999). These brains were kindly provided by Dr B. Boutrel (Department of Psychiatry, University of Lausanne, Switzerland). Per1EGFP and PER2::LUC mice were bred and supplied by the Biological Services Facility of the University of Manchester. These animals were group-housed on a $12 \mathrm{~h}$ light/dark cycle (lights on at 07:00), and with food available ad libitum. Prepro-orexin knock-out animals were bred at the University of Lausanne and maintained under similar lighting and feeding conditions as described for mice in Manchester (the absence of orexin expression is well established in these mice; Chemelli et al., 1999). All experimental procedures were performed according to the provisions of the UK Animal (Scientific Procedures) Act 1986.

\section{Preparation of living mouse SCN brain slices}

For in vitro whole-cell recordings. All brain sections were prepared during the subjective day at zeitgeber (ZT) 1-6 or 10-11 (where ZT12 corresponds to lights-off) to reduce possible phase-shifting effects of the slice preparation (Gillette et al., 1995). Coronal brain slices containing the middle level of the rostrocaudal SCN were prepared from 80 male and female Per1-EGFP mice, as previously described (Belle et al., 2009). Briefly, animals were deeply anesthetized with isoflurane and killed by decapitation. The brain was immediately removed and $250-\mu \mathrm{m}$-thick coronal slices were cut using a vibroslicer (Campden Instruments) in an ice-cold $\left(4^{\circ} \mathrm{C}\right)$ low $\mathrm{Na}^{+} / \mathrm{Ca}^{2+}$, high $\mathrm{Mg}^{2+}$ sucrose-based artificial CSF (aCSF) containing the following (in $\mathrm{mM}$ ): $95 \mathrm{NaCl}, 1.8 \mathrm{KCl}, 1.2 \mathrm{KH}_{2} \mathrm{PO}_{4}$, $0.5 \mathrm{CaCl}_{2}, 7 \mathrm{MgSO}_{4}, 26 \mathrm{NaHCO}_{3}, 15$ glucose, 50 sucrose, $0.005 \mathrm{mg} / \mathrm{L}$ Phenol Red, oxygenated with $95 \% \mathrm{O}_{2}, 5 \% \mathrm{CO}_{2}, \mathrm{pH} 7.4$, and measured osmolarity 300-310 mOsmol $/ \mathrm{kg}$. For whole-cell patch-clamp recordings, slices were transferred to a recording chamber and continuously perfused $(3 \mathrm{ml} / \mathrm{min})$ with recording aCSF. The composition of the recording aCSF was identical to the incubation solution except for the following (mM): $127 \mathrm{NaCl}, 2.4 \mathrm{CaCl}_{2}, 1.3 \mathrm{MgSO}_{4}$, and 0 sucrose. In recordings where Low $\mathrm{Ca}^{2+} /$ high $\mathrm{Mg}^{2+}$ were required, the aCSF contained $0.3 \mathrm{~mm} \mathrm{Ca}^{2+}$ and $9 \mathrm{~mm} \mathrm{Mg}^{2+}$ (Burdakov et al., 2006). Recordings were performed at $23^{\circ} \mathrm{C}$.

For in vitro luminometry recordings. SCN brain slices from PER2::LUC mice were prepared as described previously (Guilding et al., 2009). Briefly, mice were culled by cervical dislocation following isoflurane anesthesia. Brains were then removed and moistened with ice-cold HBSS (Sigma) supplemented with $0.035 \%$ sodium bicarbonate (Sigma), $10 \mathrm{~mm}$ HEPES (Sigma), and $100 \mu \mathrm{g} / \mathrm{ml}$ penicillin-streptomycin (Gibco Invitro- gen). Coronal brain slices ( $250 \mu \mathrm{m}$ thick) were cut using a vibroslicer (Camden Instruments) and transferred to sterile tissue culture dishes (Corning) in cold HBSS. Using a dissecting microscope, the SCN were identified and microdissected before excised unilateral SCN nuclei were cultured on interface-style cell culture inserts (PICM0RG50; Millipore) in standard $35 \mathrm{~mm}$ plastic-based cultures dishes (Corning). One milliliter of sterile culture medium [DMEM (D-2902; Sigma) supplemented with $3.5 \mathrm{~g} / \mathrm{L}$ D-glucose (Sigma), $0.035 \%$ sodium bicarbonate (Sigma), 10 mM HEPES buffer (Sigma), $25 \mu \mathrm{g} / \mathrm{ml}$ penicillin-streptomycin (Gibco), B27 (Invitrogen) and $0.1 \mathrm{~mm}$ luciferin (Promega) in autoclaved Milli-Q water] was used per culture. Dishes were sealed with a glass coverslip using autoclaved high-vacuum grease (Dow Corning) and transferred directly to light-tight incubators (Galaxy R+; RS Biotech) equipped with photomultiplier tube assemblies (H8259/R7518P; Hamamatsu) for photon acquisition (integrated for $299 \mathrm{~s}$ every $3 \mathrm{~min}$ ). The incubators were maintained at $37^{\circ} \mathrm{C}$.

\section{Whole-cell recordings}

Targeted recordings (current clamp or voltage clamp) were made from Per1-EGFP-positive (henceforth referred to as Per1-EGFP) neurons, visually identified using a Leica epifluorescent microscope (DMLFS; Leica Microsystems) equipped with a Leica camera and capturing software (DFC 350 FX and Application Suite; Leica Microsystems), as previously described (Belle et al., 2009; Scott et al., 2010). Final gigaohm seal and cell membrane rupture were done under infrared video-enhanced differential interference contrast microscopy. For current-clamp recordings an Axoclamp 2A amplifier (Molecular Devices) in bridge mode was used (Belle et al., 2009). Patch pipette electrodes (7-10 M $\Omega$ ) were fashioned from thick-walled borosilicate glass capillaries (Harvard Apparatus) using a two-stage vertical micropipette puller (PB-7; Narishige). Unless otherwise stated, electrodes were filled with an internal solution containing the following (in $\mathrm{mM}$ ): $130 \mathrm{~K}$-gluconate, $10 \mathrm{KCl}, 2 \mathrm{MgCl}_{2}, 2 \mathrm{~K}_{2}$-ATP, $0.5 \mathrm{Na}-\mathrm{GTP}, 10 \mathrm{HEPES}$, and $0.5 \mathrm{EGTA}, \mathrm{pH}$ adjusted to 7.3 with $\mathrm{KOH}$, measured osmolarity $295-300 \mathrm{mOsmol} / \mathrm{kg}$ ). In some recordings, $\mathrm{K}$-gluconate was substituted for equimolar $\mathrm{KCl}$. Input resistance $\left(R_{\text {input }}\right)$ was estimated by a series of hyperpolarizing current pulses $(-10$ to -30 pA for $500 \mathrm{~ms}$ ). Signals were sampled at $30 \mathrm{kHz}$, and stored and analyzed on a personal computer using Spike2 software (Cambridge Electronic Design, CED). All data acquisition and step protocols were generated through a micro $1401 \mathrm{mkII}$ interface (CED).

Synaptic current measurement. Synaptic current activity was measured with an Axopatch 200B amplifier (Molecular Devices). To record miniature and spontaneous postsynaptic currents (mPSCs and sPSCs, respectively), patch pipettes $(4-6 \mathrm{M} \Omega$ ) were filled with an internal solution that was identical to the one used in current-clamp recordings, except for $120 \mathrm{~mm} \mathrm{~K}$-gluconate and $20 \mathrm{KCl} \mathrm{mM}$. In SCN neurons, this concentration of $\mathrm{Cl}^{-}$in the intracellular pipette solution causes the IPSCs to reverse between -40 to $-50 \mathrm{mV}$ (data not shown; but see Itri and Colwell, 2003). This positive shift in $\mathrm{Cl}^{-}$reversal potential causes both GABA and glutamate PSCs to appear as inward currents when membrane voltage is clamped at $-70 \mathrm{mV}$. To discriminate between excitatory and inhibitory PSCs, a mixture of receptor antagonists (D-2-amino-5-phosphonopentanoate, AP-5; 6-cyano-7-nitroquinoxaline-2,3-dione, CNQX; and 2,3-dioxo-6nitro-1,2,3,4-tetrahydrobenzo[f] quinoxaline-7-sulfonamide, NBQX) for the glutamate receptors and/or for the $\mathrm{GABA}_{\mathrm{A}}$ receptor (gabazine) were used. All recording protocols were similar to established methods for measuring PSCs in SCN neurons (Itri and Colwell, 2003).

Whole-cell leak $\mathrm{K}^{+}$current measurement. Slow voltage ramps from 0 to $-120 \mathrm{mV}$, at a rate of $20 \mathrm{mV} / \mathrm{s}$, were performed using patch pipettes (3-5 $\mathrm{M} \Omega$ ) filled with an internal solution that was identical to the one used in previous current-clamp recordings above. These ramps were sufficiently slow to allow background leak currents to achieve steady-state conductance at each potential (Liu et al., 2002; Jackson et al., 2004). Pipette and cell capacitive transients were compensated. Membrane series resistance was $<20 \mathrm{M} \Omega$ and was compensated (70-80\%). Seal resistance was typically $\geq 10 \mathrm{G} \Omega$, and access resistance $\leq 20 \mathrm{M} \Omega$. Recordings in which the series resistance changed by $>15 \%$ were not included for analysis. Signals for voltage-clamp recordings were acquired using pClamp 10.2 and analyzed off-line using Clampfit 10.2 (Molecular Devices). All data acqui- 
sition and ramp protocols under voltage-clamp conditions were generated through a Digidata 1440 A interface using the pClamp software (Molecular Devices).

\section{Calcium imaging}

SCN brain slices ( $200 \mu \mathrm{m}$ thick) were prepared from 2- to 6-month-old Per1-EGFP mice $(n=18)$, as described above. Multiple SCN neurons maintained in these hypothalamic slices were loaded with the leakageresistant calcium-sensitive dye fura-2 AM (LeakRes fura-2; TEFlabs; 1 mM stock made on the day of the experiment in 20\% Pluronic F-127 in dimethylsulfoxide (DMSO); Molecular Probes/Invitrogen) for recording of intracellular calcium responses simultaneously in all loaded cells (Fig. 2A). Methods for calcium loading were modified from previous work on SCN and other hypothalamic neurons (Irwin and Allen, 2007, 2010; Yuste et al., 2011). Here, hypothalamic slices containing the midrostrocaudal section of the SCN were incubated with LeakRes fura-2 AM $(10 \mu \mathrm{M})$ in well gassed $\left(95 \% \mathrm{O}_{2}\right.$ and $\left.5 \% \mathrm{CO}_{2}\right) \mathrm{aCSF}$ at $37^{\circ} \mathrm{C}$ for $20 \mathrm{~min}$, followed by $1 \mathrm{~h}$ incubation at room temperature. During incubation, the gaseous composition immediately above the aCSF in which the SCN slices were kept was maintained at $95 \% \mathrm{O}_{2}$ and $5 \% \mathrm{CO}_{2}$. Following incubation, slices were washed in gassed aCSF for $1.5 \mathrm{~h}$ in a holding chamber to allow for fura-2 AM de-esterification. The SCN brain slices were then transferred to a recording chamber and maintained in a continuous flow of aCSF (1-2 ml/min). The composition of the aCSF used for calcium imaging was similar to the recording solution used for electrophysiology, except phenol red was omitted to avoid any optical distortion of the fluorescent images. Ratiometric intracellular calcium $\left(\left[\mathrm{Ca}^{2+}\right]_{\mathrm{i}}\right.$ ratio) levels were measured from pairs of backgroundsubtracted intensity images ( 14 bit, $1.24 \times 1.24$ mega pixels) captured every $2 \mathrm{~s}$ at $510 \mathrm{~nm}$ by a cooled Rolera EM-C ${ }^{2}$ camera (QImaging) from excitation wavelengths at $365 \mathrm{~nm}$ (isosbestic point for fura-2) and 385 $\mathrm{nm}$. Here, a rise or drop in $\left(\left[\mathrm{Ca}^{2+}\right]_{\mathrm{i}}\right.$ levels caused an increase or decrease in F365/F385 wavelengths, respectively. The sensitivity of this camera system allows minimal light exposure of SCN neurons at these excitation wavelengths, which significantly prolongs recording time with minimal photo-bleaching. All calcium imaging was done on an upright Olympus microscope using a water-immersion UV objective (UMPlanFL N 20×/ 0.5 Olympus). Florescence was excited by 365 and $385 \mathrm{~nm}$ Opto-LightEmitting Diodes (OptoLED; Cairn Research; Briston et al., 2011), controlled by the acquisition software OptoFluor (Cairn Research and Molecular Devices). Image capture and analysis were done in OptoFluor (Cairn Research). Acquisition time, camera setup, and LED intensities were adjusted to minimize photo-bleaching while maintaining excellent signal-to-noise ratio. Intracellular calcium response (increase, decrease, or no effect) to OXA in the presence/absence of various antagonists was defined by a ratio change $\geq 2 \times$ SDs from the mean of 10 baseline calcium ratios recorded before OXA application (Irwin and Allen, 2010). The magnitude of calcium response was determined as the maximal response after 3 min of OXA application.

\section{Drugs and analysis}

Stock solutions for an orexin receptor $1\left(\mathrm{OX}_{1}\right)$ antagonist (SB 334867), quinidine, and $\mathrm{GABA}_{\mathrm{B}}$ receptor antagonist (CGP55845) were prepared by dissolving in DMSO: final concentration of DMSO in extracellular solutions did not exceed $0.001 \%$. OXA, tetrodotoxin (TTX), AP-5, CNQX, NBQX, quinine, and gabazine (Tocris Bioscience) were dissolved in aCSF and NPY (Tocris Bioscience) in purified water. 1,2-Bis(2aminophenoxy) ethane- $N, N, N^{\prime}, N^{\prime}$-tetraacetic acid (BAPTA) and all other drugs were purchased from Tocris Bioscience.

Unless specified, all drugs were bath applied in aCSF. Where necessary, a brief focal application of drugs was delivered to the recorded neurons with a quartz puffer pipette micro-manifold (QMM) fitted to a computer-controlled pressurized drug delivery system (ALA Instruments). The QMM comprised of 12 individual microcapillaries converging into a single tip, which had a diameter of $250 \mu \mathrm{m}$, and was positioned in-line with the recorded neuron at a close distance to the SCN (Fig. 2). Under this configuration, drugs were delivered only to the SCN.

During current-clamp recordings OXA was bath applied for $3 \mathrm{~min}$, and the cell's activity and/or resting membrane potential (RMP) were allowed to return to, or closely to, predrug baseline levels before any subsequent drug treatments. The effects of drug treatment on spontaneous firing rate (SFR), RMP, sPSCs, or mPSCs were sampled in gap-free acquisition mode. Responses to OXA were defined by a change in RMP that was greater than $\pm 2 \mathrm{mV}$. The duration (min) of OXA-induced change in RMP was measured by the time taken for the cell's RMP value to depart from the predrug baseline level to the time it returned to, or close to, the baseline values. The amplitude $(\mathrm{mV})$ was measured by calculating 1 min averages of the RMP at predrug baseline level and at the maximum steady-state change in RMP during OXA application. The amplitude was obtained by subtracting these two values. Recording aCSF (drug-free or containing drugs) solution was applied to SCN slices by gravity-feed bath perfusion. Dose-dependent responses of SCN neurons to 40,60 , and $80 \mathrm{~nm}$ OXA were performed using the puffer pipette manifold, positioned close to the SCN (see above).

The mediating effects of OXA on NPY's inhibitory actions on SCN Per1-EGFP cells were tested by comparing the amplitude and duration of membrane hyperpolarization to NPY in the presence and absence of bath application of OXA (Fig. 8). First, the response of each cell to two consecutive brief focal applications of NPY (40 nM) was tested (Fig. 8A) using the puffer pipette manifold placed close to the SCN. Following the recovery of the neuron's RMP to baseline values, OXA was bath applied. A positive steadystate current injection was used to counteract any hyperpolarizing effect of OXA by returning the RMP of the cells to pre-OXA baseline levels. Then in the presence of OXA, the cell's response to NPY was again tested (Fig. 8). Because SCN cells showed heterogeneity in their sensitivity to NPY, the duration of NPY application varied from cell to cell, but to ensure comparability of the responses the duration/volume of its repeated application to each neuron was identical, and this was accurately timed through the micro $1401 \mathrm{mkII}$ interface by the Spike2 software.

Groups of cells were statistically compared using ANOVA with post hoc comparison (Sidak where repeated measures were required) or paired/unpaired $t$ test (SPSS version 16 and 20). For these tests, $p<0.05$ was considered significant. All numerical data both in text and in graphs represent mean \pm SEM. Analysis of PSC frequency and amplitude were conducted off-line by template-based sorting using Clampfit 10.2 (Molecular Devices). Synaptic events were detected with an amplitude threshold of $10 \mathrm{pA}$. The Kolmogorov-Smirnov (K-S) test was used for statistical comparisons of amplitude and interevent interval distributions of PSCs. Cumulative probability distributions were considered significantly different with a $p$ value $<0.01$ (K-S test). No overt gender differences were found in any of the electrophysiological or calcium imaging parameters measured, so all data obtained from the male and female mice were appropriately pooled.

\section{SCN slice culture}

On the fourth day after cull/culture preparation, SCN slice cultures were treated with OXA ( $80 \mathrm{~nm})$, NPY (50 nм or $200 \mathrm{~nm})$, or both at circadian time (CT) 5 (middle of the day) or CT17 (middle of the night). Treatment times were calculated as projections from the light-dark cycle under which mice were housed before cull, and drugs were delivered as a 1 $\mu \mathrm{l} 1000 \times$ concentrate microdrop directly into the existing culture medium. No two unilateral SCN cultures from the same slice were treated with the same drug. Raw luminometry data were processed by subtracting a $24 \mathrm{~h}$ running mean to remove long-term trends (baseline subtracted) then smoothed with a $3 \mathrm{~h}$ running average (Hughes et al., 2011). To assess phase shifts, a period for each individual tissue explant was calculated as peak-peak duration averaged across three cycles, discounting the first $24 \mathrm{~h}$ of data. This period was used to calculate a projected peak phase for the cycle after drug treatments, and phase shifts were measured as the time difference between this projected phase and actual peak phase for that cycle. Statistically significant differences between groups were determined using $t$ test for $200 \mathrm{~nm}$ data and ANOVA with a priori pairwise comparisons for all other comparisons; $p<0.05$ is required for significance.

\section{Immunofluorescence}

Six adult Per1-EGFP mice (three males and three females) were terminally anesthetized with pentobarbital $(80 \mathrm{mg} / \mathrm{kg})$ and they were perfused 
transcardially with $25 \mathrm{ml}$ of a balanced Kreb's solution, followed by $25-50 \mathrm{ml}$ of ice-cold $4 \%$ paraformaldehyde in $0.1 \mathrm{M}$ PBS ( $\mathrm{pH}$ 7.4). Animals were perfuse fixed at ZT8-12 to maximize EGFP signal in the SCN. Prepro-orexin knock-out mouse brains (University of Lausanne) were fixed using similar protocols to those outlined. The brains were removed, postfixed in the same fixative buffer for $4 \mathrm{~h}$, and stored for $2 \mathrm{~d}$ in $30 \%$ sucrose at $4^{\circ} \mathrm{C}$. The tissues were then flash-frozen in cooled isopentane and cut (40 $\mu \mathrm{m}$ thick) on a freezing sledge microtome (Bright Instruments). After washing in $0.1 \mathrm{M} \mathrm{PBS}$, the $40-\mu \mathrm{m}$-thick brain sections were incubated in Triton X-100 (0.1\% in PBS) for $20 \mathrm{~min}$, and nonspecific protein binding blocked with normal donkey serum $5 \%$ in PBS containing $0.05 \%$ Triton $\mathrm{X}-100$ ) for 30 $\mathrm{min}$. Sections were incubated for $48 \mathrm{~h}$ at $4^{\circ} \mathrm{C}$ in anti-orexin A (sc-8070; 1:1000; Santa Cruz Biotechnology). To test for antisera specificity, controls were performed on SCN brain sections prepared from prepro-orexin knock-out mice or by incubating Perl-EGFP SCN sections in a working dilution of the orexin A primary antisera that had been pre-adsorbed with $5 \mu \mathrm{M}$ orexin A peptide (Tocris Bioscience) overnight. In other control Per1-EGFP SCN sections, anti-orexin A antisera was omitted from the incubating solution. Following a $2 \mathrm{~h}$ wash. Sections were then incubated overnight in donkey anti-goat Alexa 568 secondary antibody (A-11057; Invitrogen 1:800). Although the EGFP protein was readily detectable, for more detailed anatomical analysis EGFP signal was further enhanced with a rabbit anti-GFP antibody (Invitrogen, 1:1000), followed by an overnight incubation in donkey anti-rabbit Alexa 488 secondary antibody (A-21206; Invitrogen 1:800). All primary antibodies were diluted in PBS containing $0.5 \%$ blocking serum and $0.05 \%$ Triton X-100. Secondary antibodies were diluted in PBS alone. Following further washes, sections were mounted in Vectashield anti-fade mounting medium (Vector Laboratories). Stacks of digital images were captured in series with a Leica SP5 inverted laser scanning confocal microscope (Leica Microsystems). For detailed visual inspections of putative synaptic contacts on Per1-EGFP cells by OXA-immunoreactive (OXA-ir) fibers, $3 \mathrm{D}$ projections of stacked confocal images (60 images per stack taken at $63 \times$ magnification) were made using Leica LAS AF software (Leica Microsystems).

SCN quantitative PCR for $\mathrm{OX}_{1}, \mathrm{OX}_{2}$, and Per2 genes

Quantitative real-time PCR (qRT-PCR) for $\mathrm{OX}_{1}, \mathrm{OX}_{2}$, and Per2 genes was performed on SCN tissue punches collected from Per1-EGFP mice at CT0 $(n=3)$ and CT12 $(n=3)$. Animals were kept in constant darkness to eliminate light/dark time cues $1 \mathrm{~d}$ before tissue collection, and maintained in the dark during exsanguination and brain dissection. SCN slices were cut using a vibratome (Camden Instruments) followed by micropunch dissection of the nuclei and collection into RNAlater (Sigma). Total RNA isolated from the SCN (RNeasy micro kit; Qiagen) were reverse transcribed (RNA-to-cDNA Reagents; Life Technologies) for analysis by $\mathrm{qRT}-\mathrm{PCR}$. Gene analysis was performed using SYBR Green technology (Life Technologies), and measured using a StepOnePlus Real Time PCR system (Life Technologies). $\mathrm{OX}_{1}$ and $\mathrm{OX}_{2}$ transcripts were amplified by QuantiTect primer assay (Qiagen). The following primers to mouse Per 2 were used ( $5^{\prime}$ to $3^{\prime}$ : Sense:GCCTTCAGACTCATGATGACAGA; Antisense:TTTGTGTGCGTCAGCTTTGG). $18 \mathrm{~S}$ was used as an internal control (5' to 3': Sense: ACGGAAGGGCACCACCAGGA; Antisense: CACCACCACCCACGGAATCG). Data were analyzed using the $\Delta \Delta C T$ method and are expressed relative to target gene expression at CT0. Statistical analysis was performed by a Student's $t$ test using GraphPad Prism (GraphPad Software).

\section{Results}

\section{Per1-EGFP neurons in the SCN are surrounded by}

\section{OXA fibers}

Previous neuroanatomical studies using light microscopy report that immunostaining for orexin is sparse to absent within the rodent SCN (Peyron et al., 1998; McGranaghan and Piggins, 2001; Nixon and Smale, 2005). To determine the extent to which orexin neurons innervate the mouse SCN and identify neurons potentially innervated by OXA-containing fibers, we used immunofluorescence and confocal microscopy and visualized OXA immunoreactivity in the hypothalamus of Per1-EGFP mice. OXA-ir fibers were present throughout the anterior hypothalamus. These fibers were readily visualized along the dorsal and lateral boundaries of the SCN (Fig. 1A). To determine how the innervation of the SCN by orexin cells mapped onto Per1-EGFP neurons, we used anti-GFP (GFP-ir) to further enhance visualization of Per1- 
A
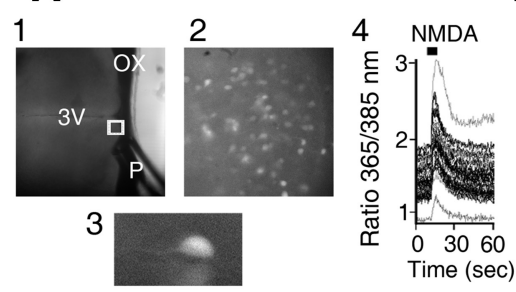

B
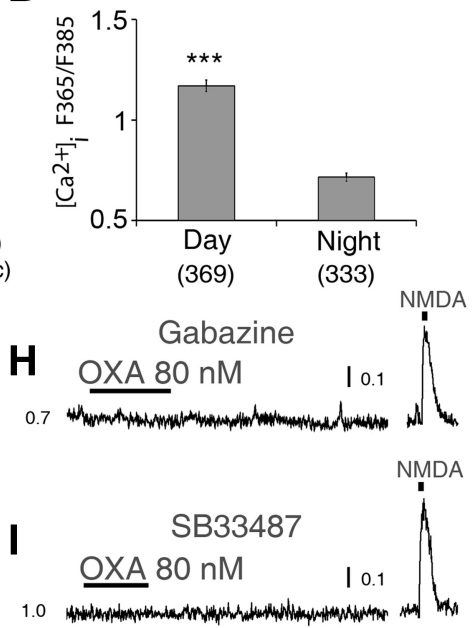

D
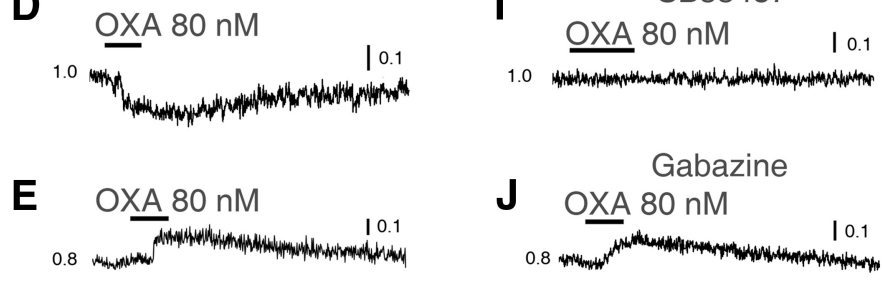

Gabazine + CGP55845
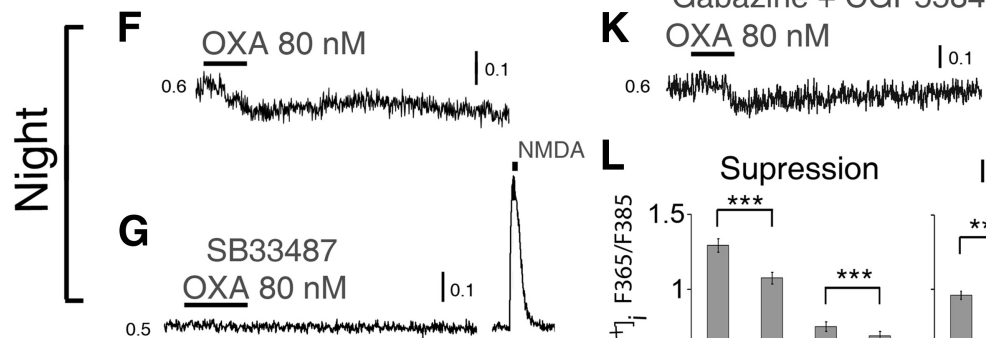

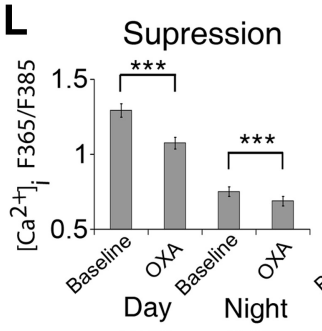

(172)

(129)

Figure 2. OXA mainly suppresses intracellular $\mathrm{Ca}^{2+}$ levels in SCN neurons. A, Simultaneous $\left[\mathrm{Ca}^{2+}\right]_{\mathrm{i}}$ measurements in multiple SCN neurons in a hypothalamic slice, with (1) recording setup with pressurized puffer pipette (P) used for brief $(5 \mathrm{~s})$ focal application of NMDA; (2) SCN neurons (40X) loaded with LeakRes fura-2 AM (taken from region in (1) marked with a white box); (3) enlarged single LeakRes fura-2 AM loaded SCN neuron; (4) representative $S \mathrm{CN}$ neurons showing transient $\left[\mathrm{Ca}^{2+}\right]_{i}$ increase in response to a focal application of NMDA (200 $\mu \mathrm{m}, 5 \mathrm{~s}$; duration black bar at top) in the late day (ZT10). B, Overall summary of measured baseline $\left[\mathrm{Ca}^{2+}\right]_{\mathrm{i}}$ level in SCN cells showing significantly higher $\left[\mathrm{Ca}^{2+}\right]_{\mathrm{i}}$ value during the day (ZT4-10) than at night (ZT16-22). During the day, 0XA (80 nM) significantly suppressed $(\boldsymbol{C}, \mathbf{D} ; n=172 / 249)$ or elevated $(\boldsymbol{E} ; n=77 / 249)$ the baseline $\left[\mathrm{Ca}^{2+}\right]_{\mathrm{j}}$ ratio in 69 and $31 \%$ of responsive $S C N$ neurons, respectively. At night, $0 X A$ decreased $(\boldsymbol{F})$ the baseline $\left[\mathrm{Ca}^{2+}\right]_{i}$ ratio in $97 \%(n=129 / 133)$ of responsive SCN neurons while increasing this ratio in only $3 \%(n=4 / 133)$ of cells (data not shown). This nighttime effect of OXA on cytosolic calcium levels in SCN neurons was insensitive to coapplication of gabazine and CGP5585 (K), GABA , and GABA receptor antagonists, respectively, but was abolished when 0XA receptor antagonist SB33487 was coapplied with OXA (G). In contrast, in the day, gabazine abolished OXA's suppression of cytosolic calcium levels in $\mathrm{SCN}$ cells $(\boldsymbol{H})$, but not its induced elevation $(\boldsymbol{J})$ of the ratio. $\mathbf{G}-\boldsymbol{I}$, In the presence of gabazine and SB33487 the cells showed an acute increase in their cytosolic calcium levels in response to a $200 \mu \mathrm{m}$ focal application (5s) of NMDA. $L$, Summary of OXA effects on $\left[\mathrm{Ca}^{2+}\right]_{\mathrm{i}}$ level in SCN cells over the day and at night. All data shown are expressed as mean $\pm \mathrm{SEM} ;{ }^{*} p<0.05,{ }^{* * *} p<0.0001$. Number of cells measured is shown in brackets. OX, optic chiasm; $3 V$, third ventricle; $P$, tip of the pressurized puffer pipette manifold.

EGFP neurons in fixed SCN brain sections and coimmunolabeled for OXA. The distribution of Per1-EGFP neurons at the mid-coronal level of the SCN (Fig. 1A) was as previously described (Kuhlman et al., 2003; Hughes et al., 2008). At this plane of the SCN, OXA-ir processes innervated many sites containing Per1-EGFP-positive and -negative (unidentified) cells. Detailed visual inspection of $3 \mathrm{D}$ rotated projections of confocal image stacks (comprised of 60 optical image slices, of $0.3 \mu \mathrm{M}$ thickness each) at higher magnification $(63 \times)$ showed varicotic OXA-ir

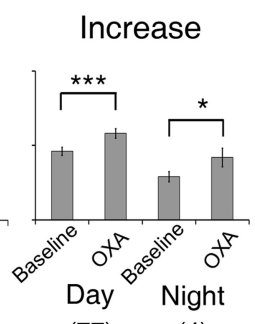

(77)

(4) axonal fibers around Per1-EGFP and other cells (Fig. 1A,a1-e3). OXA-ir axonal boutons converged and appeared to delineate the soma of these cells (Fig. $1 d 1-$ e3). In contrast, OXA-ir staining was absent in SCN brain sections from preproorexin knock-out mice (Fig. $1 B$ ), and in brain sections from Per1-EGFP mice incubated overnight with either preadsorbed OXA antisera (Fig. 1C), or with omission of OXA antisera (Fig. 1D). Figure $1, E$ and $F$, shows the nonenhanced Per1-EGFP expression of Figure 1, $C$ and $D$, respectively. These data provide neuroanatomical support for orexin release in the vicinity of Per1-EGFP neurons and other cells in the SCN.

\section{$O X_{1}$ and $O X_{2}$ receptor $m R N A s$ are expressed in the mouse SCN}

To determine whether orexin receptors are also expressed in the SCN, we performed qPCR on mouse $(n=6) \mathrm{SCN}$ brain tissue to measure the levels of mRNA transcript encoding for $\mathrm{OX}_{1}$ and $\mathrm{OX}_{2}$ receptors at circadian dawn and dusk. Our results indicate that both $O X_{1}$ and $\mathrm{OX}_{2}$ mRNA are expressed within the mouse SCN, and that $O X_{1}\left(t_{(4)}=4.33\right.$, $p<0.05)$ but not $\mathrm{OX}_{2}$ exhibited a similar profile to the core clock gene Per2 $\left(_{(4)}=\right.$ $4.29, p<0.05)$, with a significant increase in expression at dusk (CT12) relative to dawn (CT0; $t$ test; $p<0.05$; Fig. $1 G$ ).

OXA indirectly and directly suppresses intracellular $\mathrm{Ca}^{2+}$ levels in

\section{SCN neurons}

To investigate if and how OXA influences SCN cellular activity, we next determined the impact of OXA on the intracellular cytosolic calcium $\left[\mathrm{Ca}^{2+}\right]_{\mathrm{i}}$ levels in SCN neurons. To do this we loaded SCN brain slices with leakage-resistant fura-2 AM and imaged the mean $\left[\mathrm{Ca}^{2+}\right]_{\mathrm{i}}$ ratio (F365/ F385 wavelengths) of multiple SCN cells before and during OXA application across the projected day (ZT4-10) and night (ZT16-22; Fig. 2A1-A3). Figure 2A4 illustrates how multiple SCN cells can show robust increases in intracellular $\mathrm{Ca}^{2+}$ following brief focal application of NMDA. Consistent with previous work (Colwell, 2000; Ikeda et al., 2003; Irwin and Allen, 2010), the baseline cytosolic calcium levels in all SCN cells measured were significantly higher during the middle of the day (ZT4-10, $n=369$ ) than at the middle of the night (ZT16-22; $n=333 ; t_{(645.40)}=13.3, p<0.0001$; Fig. $\left.2 B\right)$. Overall, bath application of $80 \mathrm{nM}$ OXA caused significant changes (decrease or increase) in baseline cytosolic calcium levels in $\sim 67 \%$ of these SCN cells during the day (249 of 369 cells tested over ZT4-10), and $\sim 40 \%$ of neurons at night ( 133 of 333 cells tested over ZT1622 ) with remaining cells unaltered by OXA application. Of the 
responsive cells tested during the day, most (172/249 cells; 69\%) significantly reduced cytosolic calcium levels to OXA application $\left(t_{(171)}=8.32, p<0.0001\right.$; Fig. $\left.2 C, D, L\right)$, with the remaining cells (77/249) showing significant elevation in intracellular calcium levels to OXA $\left(t_{(76)}=-9.97, p<0.0001\right.$; Fig. $\left.2 E, J, L\right)$. At night, the predominant response to OXA $(80 \mathrm{nM})$ was a significant reduction in the cytosolic calcium level (129 of 133 OXA responsive cells; $97 \% ; t_{(128)}=12.34, p<0.0001$; Fig. $\left.2 F, K, L\right)$, with only a minority of cells $(4 / 133)$ showing significant elevation in $\left[\mathrm{Ca}^{2+}\right]_{i}$ $\left(t_{(3)}=-4.59, p<0.05\right.$; Fig. $\left.2 L\right)$. Hence, there is a significant time of day effect on the suppressive (day: $47 \%$ of cells tested; night: $39 \%$ ) and activational (day: $21 \%$ of all cells tested; night: $3 \%$ ) actions of OXA on the mean cytosolic calcium levels in SCN neurons. Pretreatment with an orexin receptor antagonist SB334867 (10 $\mu \mathrm{M})$ prevented cells from changing their intracellular calcium levels to subsequent treatment with OXA (regardless of time of day), but did not block cytosolic calcium responses to focal application of the glutamatergic agonist NMDA $(200 \mu \mathrm{M}$ for $5 \mathrm{~s}$; Fig. $2 G, I)$. Therefore, actions of OXA on intracellular calcium of SCN cells require activation of orexin receptors.

Intriguingly, most investigations of OXA on cytosolic calcium in neurons report that OXA elevates intracellular $\mathrm{Ca}^{2+}$, an outcome interpreted as a consequence of OXA depolarizing neurons (Kohlmeier et al., 2008). Many SCN cells are GABAergic (Moore and Speh, 1993; Buijs et al., 1994; Castel and Morris, 2000) and functional $\mathrm{GABA}_{\mathrm{A}}$ and $\mathrm{GABA}_{\mathrm{B}}$ receptors are present in the $\mathrm{SCN}$ (Strecker et al., 1997; Itri and Colwell, 2003; Moldavan et al., 2006; Irwin and Allen, 2009). To determine whether the suppressive actions of OXA involve inhibitory GABA signaling, OXAresponsive cells were retested for the responses to this neuropeptide in the presence of gabazine and CGP55845, antagonists of $\mathrm{GABA}_{\mathrm{A}}$ and $\mathrm{GABA}_{\mathrm{B}}$ receptors, respectively. During the day, blockade of GABAergic signaling abolished all of OXA's suppression of intracellular calcium in SCN cells ( $n=90$ cells tested). Figure $2 \mathrm{H}$ shows a cell that reduced intracellular $\mathrm{Ca}^{2+}$ to OXA, but not when OXA was coapplied with gabazine. Such treatment with gabazine had no effect on the subset of cells that elevated cytosolic calcium levels in response to OXA (Fig. $2 J$ ). Subsequent focal application of NMDA ( $200 \mu \mathrm{M}$ for $5 \mathrm{~s})$ caused a robust acute rise in cytosolic calcium levels in all daytime SCN cells treated with gabazine (Fig. $2 H$ ). In contrast to this reliance on GABA signaling through $\mathrm{GABA}_{\mathrm{A}}$ receptors $\left(\mathrm{GABA}-\mathrm{GABA} \mathrm{A}_{\mathrm{A}}\right.$ receptor signaling) during the day, the suppression of intracellular calcium in SCN cells by OXA at nighttime was not altered when pretreated with $20 \mu \mathrm{M}$ gabazine $(n=42$; Fig. $2 K)$. Since $\mathrm{GABA}_{\mathrm{B}}$ receptors are also present in the $\mathrm{SCN}$ region (Francois-Bellan et al., 1989; Gribkoff et al., 2003), we also determined whether blockade of GABA-GABA $\mathrm{B}$ receptor signaling influenced OXA's nighttime actions. Pretreatment with the $\mathrm{GABA}_{\mathrm{B}}$ receptor antagonist CGP5584 $(10 \mu \mathrm{M})$ did not affect subsequent responses to OXA $(n=48)$ (Fig. $2 K)$. This indicates that OXA's suppressive actions on cytosolic calcium levels of $\mathrm{SCN}$ cells require functional $\mathrm{GABA}_{\mathrm{A}}$ receptor signaling during the day, while at night neither $\mathrm{GABA}_{\mathrm{A}}$ nor $\mathrm{GABA}_{\mathrm{B}}$ receptor signaling is required for OXA's actions. Further, these data demonstrate that the elevations in intracellular calcium evoked by OXA are unaffected by blockade of GABAergic mechanisms.

In summary, the cytosolic calcium experiments establish that OXA acts principally to suppress rather than elevate levels of intracellular calcium, thereby indicating that OXA is unlikely to depolarize the majority of SCN cells, or that if it does, then this occurs via mechanisms that do not increase intracellular calcium. Since intracellular $\mathrm{Ca}^{2+}$ levels are associated with the intrinsic electrical state of SCN neurons (Diekman et al., 2013), these results suggest that OXA should mostly suppress SCN neuronal activity.

\section{Day-night differences in the actions of OXA on SCN neurons}

To determine whether SCN neurons responsive to OXA contain clock genes and to evaluate how this neuropeptide alters the intrinsic electrical properties of SCN neurons, we used epifluorescence and performed targeted whole-cell current-clamp recordings from identified Per1-EGFP $(n=162)$ neurons in SCN brain slices $(n=55)$. We tested how bath application of OXA ( 80 $\mathrm{nm}$ for $3 \mathrm{~min}$ to achieve a steady-state concentration in the bath) altered the bioelectric activities [RMP, $R_{\text {input }}$, and SFR of action potentials (APs)] of Per1-EGFP neurons. Since the electrical activity of SCN neurons varies across the circadian cycle (Brown and Piggins, 2007; Colwell, 2011) and can influence how these cells respond to neurochemicals (Piggins et al., 1994), we recorded and compared OXA's action across a $10 \mathrm{~h}$ epoch of the projected day (ZT2-12) and $6 \mathrm{~h}$ epoch of the projected night (ZT16-22). Consistent with previous reports (Kuhlman et al., 2003; Belle et al., 2009; Scott et al., 2010), SCN Per1-EGFP neurons were more active during the day than the night. Significant day-night differences were seen in mean RMP $(-40.3 \pm 0.9 \mathrm{mV}$ vs $\left.-49.1 \pm 1 \mathrm{mV} ; t_{(155.62)}=13.78, p<0.001\right)$ and $R_{\text {input }}(1.9 \pm$ $0.1 \mathrm{G} \Omega$ vs $\left.1.5 \pm 0.03 \mathrm{G} \Omega ; t_{(102.43)}=6.97, p<0.001\right)$. With the exception of the middle to late projected day (ZT6-9), when some Per1-EGFP neurons stop generating APs by depolarization blockade (Belle et al., 2009; Scott et al., 2010), daytime Per1-EGFP cells showed elevated SFR compared with the low to moderate frequencies recorded at night $(2.9 \pm 0.3 \mathrm{~Hz}$ vs $1.7 \pm 0.2 \mathrm{~Hz}$; $\left.t_{(83.46)}=4.3, p<0.001\right)$.

Across the projected circadian cycle, the majority of Per1EGFP SCN neurons tested responded to OXA (119/162; 73\%), with inhibitory hyperpolarizing actions predominating (100/119 responsive cells; 84\%; Fig. $3 A, C, E$ ). Further, OXA-induced hyperpolarizations were significantly longer in duration at night than those elicited during the day $(54.8 \pm 4.4 \mathrm{~min}$ vs $14.2 \pm 1.5$ $\left.\min ; t_{(72.33)}=-13.43, p<0.0001\right)$. In the remaining $16 \%$ of responsive Per1-EGFP cells (19/119), OXA caused excitation with associated significant increase in AP discharge during the day $\left(t_{(18)}=-11.99, p<0.0001\right.$; Fig. $\left.3 G, I\right)$, but not at night. This tendency for OXA to suppress excitability of SCN neurons was also seen in our previous in vitro extracellular recordings (Brown et al., 2008), and in preliminary investigations we have also observed this in in vivo extracellular recordings (data not shown). Independent of the polarity of the response or time of day, OXAresponsive Per1-EGFP SCN cells did not respond to this neuropeptide when tested in the presence of the OXA receptor antagonist SB334867 (10 $\mu \mathrm{M}$; Fig. 3B; day and F; night, for example); thus indicating the dependence of OXA responses in the SCN on orexin receptor activation.

\section{Mechanisms of OXA signaling in SCN Per1-EGFP neurons in vitro}

Hyperpolarizations evoked by OXA during the day were not associated with changes in $R_{\text {input }}(1.9 \pm 0.1 \mathrm{G} \Omega$ vs $1.8 \pm 0.2 \mathrm{G} \Omega$; paired $t$ test, $p>0.05)$, whereas at night, $R_{\text {input }}$ was significantly reduced $\left(1.6 \pm 0.1 \mathrm{G} \Omega\right.$ vs $0.8 \pm 0.1 \mathrm{G} \Omega ; t_{(29)}=17.12, p<0.001$, paired $t$ test). This indicates day-night differences in the potential contribution of $\mathrm{K}^{+}$conductances, and presynaptic and postsynaptic mechanisms to the hyperpolarizing actions of OXA. To evaluate contributions of presynaptic and postsynaptic mechanisms to these actions of OXA, cellular responses of orexin- 


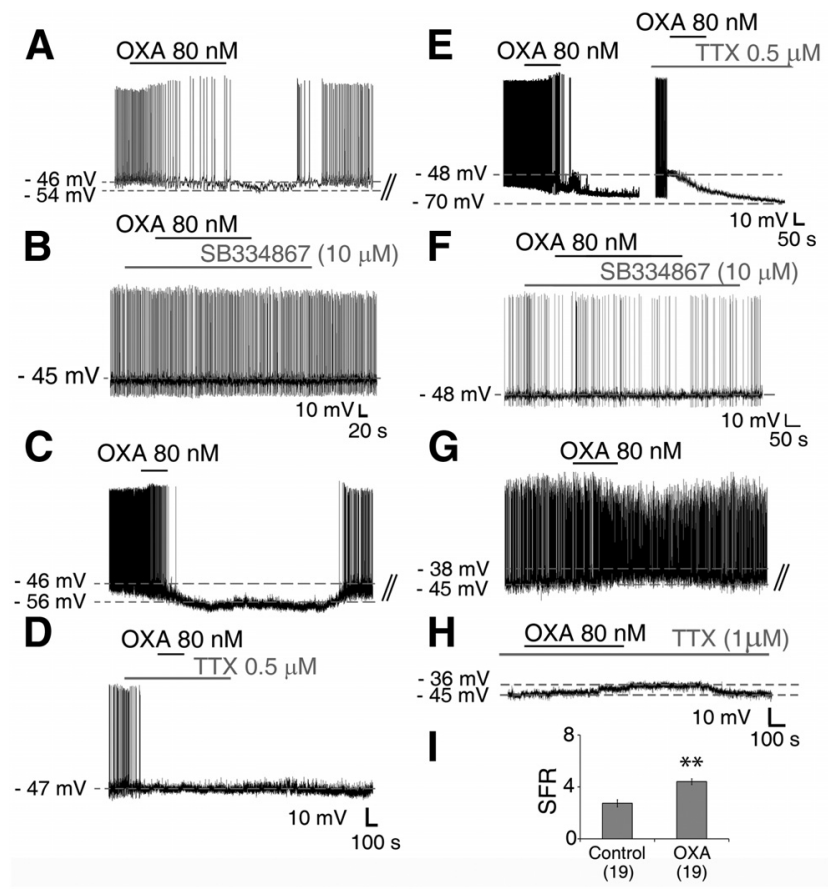

Figure 3. OXA directly activates and indirectly suppresses Per1-EGFP neuronal activity during the day. $\boldsymbol{A}$, Typical inhibitory response of an SCN Per1-EGFP cell to bath application of OXA during the projected day caused membrane hyperpolarization and suppression of AP firing. $A$, $\boldsymbol{B}, \boldsymbol{F}$, Whole-cell recordings from Per1-EGFP neurons during the day $(\boldsymbol{A}, \boldsymbol{B})$ and at night $(\boldsymbol{F})$ showing that the orexin receptor antagonist, SB334867 (10 $\mu \mathrm{M})$, had no effect on membrane excitability, but prevented the hyperpolarizing actions of OXA. C-E, TTX (0.5 $\mu \mathrm{m})$, given to cells responsive to OXA in control aCSF $(\boldsymbol{C})$, abolished inhibitory responses to OXA during the day $(\boldsymbol{D})$, but not at night ( $\boldsymbol{E}$; showing two cells hyperpolarized with OXA in the presence or absence of TTX in the a(SF). This establishes a clear day-night difference in the actions of OXA in the SCN, and shows that stimulation of orexin receptors during the day activates indirect AP-dependent inhibitory neurotransmission mechanisms, whereas at night this stimulation of orexin receptors directly inhibits Per1-EGFP neuronal activity. $\mathbf{G}, \boldsymbol{H}$, OXA caused membrane depolarization in SCN Per1-EGFP neurons recorded during the day ( $G$ ), which persisted when OXA was coapplied with TTX $(1 \mu \mathrm{M})$ in the bath $(\boldsymbol{H})$, indicating postsynaptic (direct) excitation. $\boldsymbol{I}$, In the absence of TTX, this depolarizing effect of OXA on Per7-EGFP was accompanied with a significant increase in firing rate. $\boldsymbol{B}, \boldsymbol{D}, \boldsymbol{H}$, Consecutive traces from $\boldsymbol{A}, \boldsymbol{C}$, and $\boldsymbol{G}$, respectively. ${ }^{* *} p<0.01$. All data shown are expressed as mean \pm SEM. Number of cells measured is shown in parentheses.

responsive neurons were retested to this neuropeptide in the presence of TTX-containing aCSF. TTX concentrations (0.5-1 $\mu \mathrm{M})$, that block most voltage-dependent sodium channel conductances and hence AP-dependent synaptic communication, abolished inhibitory responses to OXA during the day ( 8 of 8 responsive cells; Fig. $3 C, D)$, but not at night ( 0 of 8 responsive cells; Fig. 3E). Indeed, during the day when TTX was continuously bath applied before OXA treatment to a different cohort of neurons, none of these cells tested hyperpolarized to OXA ( 0 of 7 cells tested; data not shown). This indicates that during the day, OXA recruits presynaptic mechanisms to indirectly suppress neuronal activity in the SCN, whereas at night, it acts directly to hyperpolarize the cells.

Similar to the direct hyperpolarizing actions of OXA at night, daytime SCN neurons depolarized by OXA given in control aCSF also depolarized to OXA when AP-dependent communication was blocked by pretreatment with TTX (Fig. 3G, $H$ ). These findings establish a profound day-night difference in the actions of OXA in the SCN and suggest that stimulation of orexin receptors during the day activates indirect inhibitory neurotransmission mechanisms, whereas at night this stimulation of orexin receptors directly inhibits SCN neuronal activity.
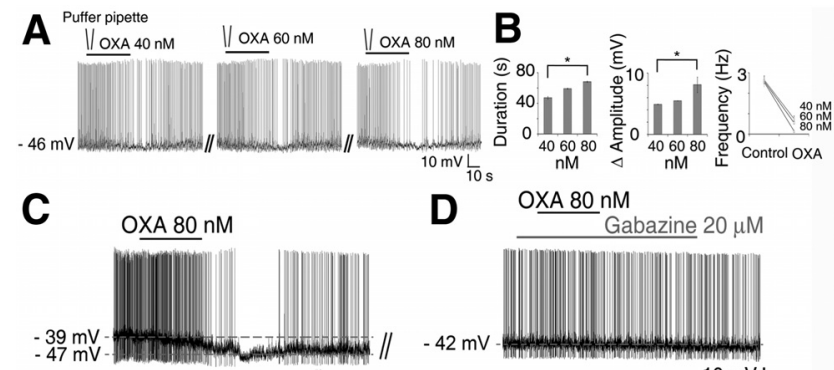

D OXA $80 \mathrm{nM}$

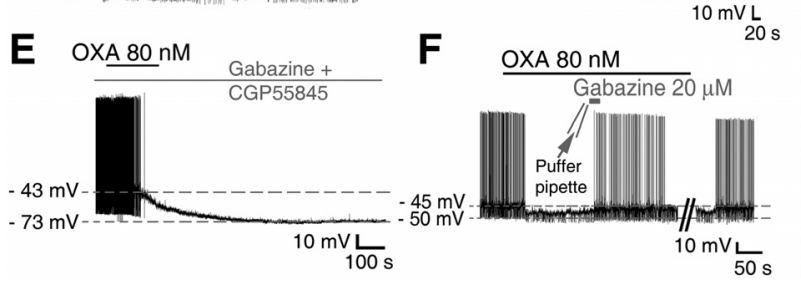

Figure 4. Blockade of GABA receptors abolishes the suppressive actions of OXA on Per1-EGFP cells during the day but not at night. $A$, Representative consecutive whole-cell recording made from a Per1-EGFP neuron at ZT4, showing dose-related hyperpolarizing responses to focally applied (duration $=35 \mathrm{~s}$ ) 40,60, and $80 \mathrm{~nm}$ OXA. B, Summary of responses from four Per1-EGFP cells to focally applied OXA doses. $C, E$, Whole-cell recordings from Per1-EGFP neurons showing OXA causing membrane hyperpolarization and suppression of AP firing in the day $(\boldsymbol{C})$ and at night $(\boldsymbol{E})$. $C, \boldsymbol{D}$, Cotreatment of Per1-EGFP neurons suppressed by OXA in control aCSF $(\boldsymbol{C})$ with the $\mathrm{GABA}_{\mathrm{A}}$ receptor antagonist, gabazine $(20 \mu \mathrm{M})$, blocked the hyperpolarizing actions of OXA during the day (D).E, In contrast, cotreatment of Per1-EGFP cells with gabazine $(20 \mu \mathrm{M})$ and the $G_{A B A_{B}}$ receptor antagonist CGP55845A $(10 \mu \mathrm{m})$ at night did not prevent OXA-induced hyperpolarization in these cells. $\boldsymbol{F}$, Typical membrane potential response of Per1-EGFP cells to a brief focal application of gabazine ( $20 \mu \mathrm{m}$ in a puffer pipette for $20 \mathrm{~s}$ ) during OXA bath application in the day, which transiently blocked OXA-induced hyperpolarization in these cells. This reinforces the reliance of $O X A$ on functional $G A B A_{A}$ receptor signaling during the day to suppress electrical activity of Per1-EGFP cells. $\boldsymbol{D}$ is a consecutive trace from $\boldsymbol{C}$. ${ }^{*} p<0.05$. All data shown are expressed as mean \pm SEM.

To investigate whether OXA applied directly to the SCN would also inhibit Per1-EGFP neurons, we focally applied 40, 60, and $80 \mathrm{~nm}$ OXA to daytime recorded Per1-EGFP cells, by a pressurized puffer pipette placed close to the SCN (Fig. 2A1). This permits three consecutive brief pulses (35 s duration each) of OXA to be quickly delivered to the SCN, allowing shorter recovery time for the cells between each OXA dose than with bath application (Fig. 4A). As shown in Figure 4, $A$ and $B$, focal application of OXA causes suppression of RMP and SFR of SCN cells $(n=4)$ in a dose-related manner (RMP amplitude: $F_{(2,6)}=54.92$, $p<0.001$; and duration: $F_{(2,6)}=467.21, p<0.001$; SFR: $F_{(2,6)}=$ $8.22, p<0.05)$. Analysis from four Per1-EGFP neurons tested with these doses of OXA showed that the suppressive action of OXA (lowering of RMP and SFR) was not different at 40 and 60 nм doses $(p>0.05)$. In contrast, $80 \mathrm{~nm}$ OXA produced suppression in baseline RMP $(p<0.001)$ and SFR $(p<0.05)$ that was significantly larger than effects seen with $40 \mathrm{~nm}$ OXA. Focal applications of aCSF alone had no effect on membrane excitability in these cells (data not shown).

The direct depolarizing actions of OXA on central neurons in many brain sites are well described (Kukkonen and Akerman, 2005; van den Pol and Acuna-Goycolea, 2005; Eriksson et al., 2010), whereas its inhibitory effects are less frequently reported and poorly understood. Therefore, we subsequently focused on the mechanisms of OXA-induced hyperpolarization.

\section{GABAergic signaling is differentially recruited from day to night}

As revealed above, the TTX sensitivity of OXA-induced hyperpolarization of Per1-EGFP neurons during the day indicates an 
underlying presynaptic mechanism. In line with the OXA-induced suppression of intracellular calcium, the inhibitory daytime actions of OXA on Per1-EGFP neurons were blocked (16 of 16 OXAresponsive cells) by coapplying OXA with the $\mathrm{GABA}_{\mathrm{A}}$ receptor antagonist gabazine $(20 \mu \mathrm{M} ;$ Fig. $4 D)$. In contrast, at night, neither coapplication of gabazine $(20 \mu \mathrm{M} ; 0$ of 8 responsive cells) nor the $\mathrm{GABA}_{\mathrm{B}}$ receptor antagonist, CGP55845A (10 $\mu \mathrm{M} ; 0$ of 7 responsive cells), prevented OXA's robust hyperpolarizing effect on Per1EGFP neurons (Fig. 4E).

To establish whether daytime application of OXA-evoked GABA release within the SCN (as opposed to extraSCN areas), gabazine $(20 \mu \mathrm{M})$ was focally applied in the SCN (20 s with a puffer pipette; diameter $250 \mu \mathrm{M}$ ) in the presence of bathapplied OXA. As shown in Figure $4 F$, brief blockade of the $\mathrm{GABA}_{\mathrm{A}}$ receptor by gabazine $(n=6)$ in the SCN abolished the hyperpolarizing action of OXA on Per1EGFP cells ( 6 of 6 cells). Together, these findings confirm that during the day, functional $\mathrm{GABA}_{\mathrm{A}}$ receptors are necessary for OXA to inhibit and alter the intrinsic state of SCN Per1-EGFP neurons, whereas at night, neither GABA-GABA nor $G A B A-G A B A_{B}$ receptor signaling is necessary for the hyperpolarizing actions of OXA.

These results demonstrate that OXA engages neural networks intrinsic to the SCN in a dose- and time-dependent manner to suppress Per1-EGFP-expressing SCN clock cells.

\section{OXA increases sPSCs and mPSCs in SCN neurons during the day}

We next assessed the effects of OXA on the frequency and amplitude of sPSCs and mPSCs in voltage-clamp recordings of Per1EGFP neurons. Measurement of sPSCs and mPSCs frequency assesses AP-dependent and -independent synaptic vesicle release, respectively, and allows us to determine whether OXA can also act directly on presynaptic terminals to cause the release of neurotransmitters in the absence of presynaptic APs (quantal release; recorded as mPSCs). Bath application of OXA produced an increase in the frequency and amplitude of sPSCs in $\sim 65 \%$ of Per EGFP cells (25/39 cells recorded; Fig. 5A,b2,C,D). In these responsive Per1-EGFP cells OXA significantly increased the mean sPSC frequency from $2.2 \pm 0.2 \mathrm{~Hz}$ (basal) to $6.4 \pm 0.8 \mathrm{~Hz}\left(t_{(24)}=\right.$ $-11.25, p<0.001$; paired $t$ test) and the amplitude from $45.6 \pm$ $2.1 \mathrm{pA}$ (basal) to $76.2 \pm 9.4 \mathrm{pA}\left(t_{(24)}=-8.77, p<0.05\right.$; paired $t$ test; Fig. $5 A$ ). Pretreatment with the orexin receptor antagonist SB334867 abolished these actions of OXA (Fig. 5E,F), indicating that they are mediated by activation of orexin receptors.

Under our intracellular recording conditions $(20 \mathrm{~mm} \mathrm{KCl}-$ filled pipettes) $\mathrm{Cl}^{-}$currents have a reversal potential of approximately $-43 \mathrm{mV}$, and thus both $\mathrm{GABA}_{\mathrm{A}}$ and AMPA/NMDA currents appear as inward currents at the holding potential that we used $(-70 \mathrm{mV})$ (Itri and Colwell, 2003). Therefore, we used
B (b1) baseline

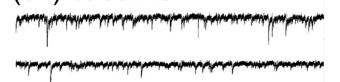

(b3) gabazine $(20 \mu \mathrm{M})$

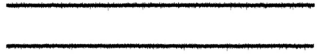

(b5) $\operatorname{TTX}(0.5 \mu \mathrm{M})$

-

(b7) TTX + OXA (80 nM)

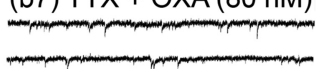

D

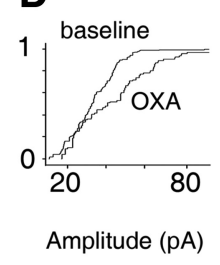

(b2) OXA (80 nM)

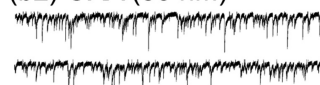

(b4) washout

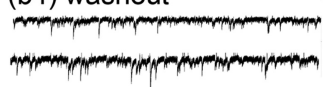

(b6) TTX + OXA (80 nM)

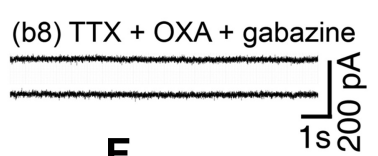

F $\quad$ SB334867

1.

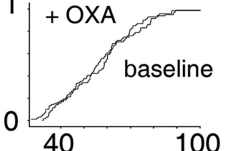

Amplitude (pA)
Figure 5. OXA increases PSCs in Per1-EGFP cells during the day. A, Summary of results from all Per1-EGFP neurons showing an receptor mediated. $\boldsymbol{B}$, Examples of traces from two individual Per1-EGFP cells (voltage clamped at $-70 \mathrm{mV} ; \boldsymbol{b} \mathbf{1}-\boldsymbol{b} \mathbf{6}$ for cell1 and (h) $\mathrm{NBQX}$, blockers of NMDA/AMPA/kainate-type glutamate receptors. ${ }^{*} p<0.05,{ }^{* *} p<0.01$. All data shown are expressed as mean \pm SEM. Number of cells measured is shown in parentheses.

receptor-selective antagonists to investigate whether the OXAinduced sPSCs were GABAergic or glutamatergic. In all OXAresponsive Per1-EGFP cells tested, OXA-induced sPSCs were insensitive to bath application of the glutamatergic receptor antagonists, AP5, CNQX, and NBQX (0 of 10 cells; data not shown). In contrast, these OXA-sensitive spontaneous events were completely abolished by bath application of gabazine $(20 \mu \mathrm{M}$ for 5 min; 10 of 10 cells; Fig. 5b3), indicating that they were $\mathrm{GABA}_{\mathrm{A}}$ receptor-mediated IPSCs. The rise time to peak of these spontaneous IPSCs was $2.9 \pm 0.3 \mathrm{~ms}$ and the time constant decay was $14.7 \pm 0.5 \mathrm{~ms}$, values that are consistent with previous observations using similar recording conditions to study $\mathrm{GABA}_{\mathrm{A}}$ receptormediated spontaneous IPSCs in SCN neurons (Itri and Colwell, 2003; Itri et al., 2004).

Bath application of TTX $(0.5 \mu \mathrm{M})$ significantly reduced or abolished the sPSCs in OXA-responsive Per1-EGFP neurons ( 9 of 9 cells; Fig. $5 A$, b5; now measured as mPSCs). However, as shown in Figure 5, $A, b 6$, and $b 7$, in the presence of TTX OXA significantly induced mPSCs frequency in the cells $\left(t_{(8)}=-4.8 ; p<\right.$ $0.01)$. These OXA-induced mPSCs were abolished by gabazine (20 $\mu \mathrm{M}$; tested in four cells), demonstrating that they were GABAergic events (Fig. 5A,b8). Therefore OXA significantly increases presynaptic release of GABA onto Per1-EGFP neurons, which leads to significant inhibition of these cells. A similar action of OXA has been reported in dorsal raphe cells (Liu et al., 2002). 
A OXA $80 \mathrm{nM}$

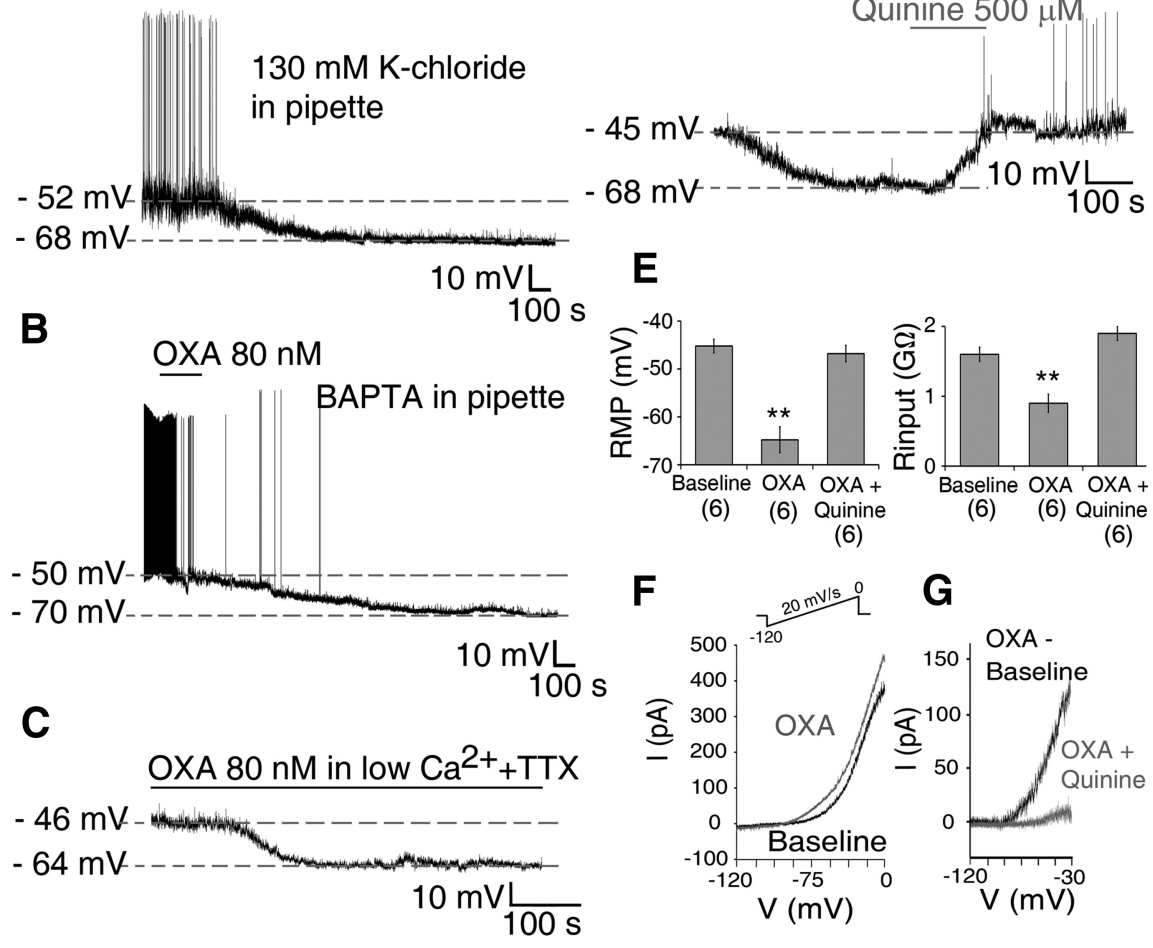

Figure 6. OXA causes direct membrane hyperpolarization and suppression of Per1-EGFP neuronal activity at night. A-C, Bath application of OXA hyperpolarized Per1-EGFP neurons, and in all cells this hyperpolarization was significantly larger in duration $(>50 \mathrm{~min}$ ) at this circadian phase than during the day. $\boldsymbol{A}, \boldsymbol{B}, 0 \mathrm{XX}$-induced suppression of Per1-EGFP cells persisted when $(\boldsymbol{A})$ intracellular $\mathrm{K}^{+}$-gluconate was substituted with equimolar $\mathrm{KCl}$ solution; $(\boldsymbol{B})$ intracellular $\mathrm{Ca}^{2+}$ solution was clamped at $<90 \mathrm{nM}$ with BAPTA-Ca ${ }^{2+}$ mixture, preventing $\mathrm{Ca}^{2+}$ mobilization from intracellular stores; and $(C)$ when $\mathrm{Ca}^{2+}$ influx was prevented with

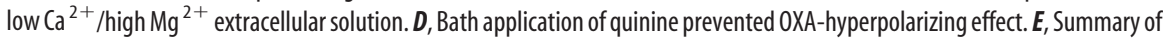
results obtained from six current-clamp cells where OXA-induced membrane hyperpolarization and accompanied reduction in $R_{\text {input }}$ were blocked when OXA was coapplied with quinine. $F, I-V$ relationship during baseline (black trace) and in the presence of OXA (gray trace) obtained by slowly ramping the membrane voltage (see Materials and Methods and inset). $\boldsymbol{G}$, Net OXA current obtained by subtracting $0 X A I-V$ from control $I-V$ (black trace), with quinine potently inhibiting this $0 X A$-induced current (gray trace). ${ }^{* *} p<0.01$. Data are expressed as mean \pm SEM. Number of cells measured is shown in parentheses.

on OXA-induced inhibition at night ( $n=$ 4: data not shown). Thus, dialyzing the neurons with $10 \mathrm{~mm}$ BAPTA (a rapid $\mathrm{Ca}^{2+}$ buffer) coupled with $2 \mathrm{mM} \mathrm{Ca}^{2+}$ (thereby clamping cytosolic $\mathrm{Ca}^{2+}$ ) did not prevent OXA's action. Together, these results show that neither $\mathrm{Ca}^{2+}$ entry, nor its release from intracellular stores, is critical for OXA's hyperpolarizing action. This strongly indicates that $\mathrm{Ca}^{2+}$-activated $\mathrm{K}^{+}$ channels, which in Per1-EGFP cells can show increased conductance at night (Pitts et al., 2006), are unlikely to be involved in OXA's nocturnal actions.

Previously, OXA has been shown to increase excitability of thalamic cells by suppressing the activity of leak $\mathrm{K}^{+}$conductance (Govindaiah and Cox, 2006). Considering the robust and long-lasting hyperpolarizing effect we observe during nighttime administration of OXA, and the very slow onset, and postsynaptic nature of this response, we tested whether OXA was activating background leak $\mathrm{K}^{+}$channels to hyperpolarize SCN neurons at this time. We first investigated this in currentclamp recordings to see if the blockade of leak $\mathrm{K}^{+}$channels prevented OXA's inhibitory action. We challenged OXA responsive neurons with quinine or quinidine $(500 \mu \mathrm{M})$, two broad-spectrum leak $\mathrm{K}^{+}$ channel inhibitors (Lotshaw, 2007). Both, quinine $\left(\mathrm{RMP}: F_{(2,10)}=25.55, p<0.001\right.$; $R_{\text {input }}: F_{(2,10)}=17.47, p<0.01, n=6$; Figure $6 D, E)$ and quinidine $\left(\operatorname{RMP}: F_{(2,6)}\right.$ $=50.41, p<0.001 ; R_{\text {input }}: F_{(2,6)}=25.06$, $p<0.001, n=4$; data not shown) reversed OXA-induced hyperpolarization, returning the RMP (post hoc tests for qui-

\section{OXA hyperpolarizes SCN cells at night by opening leak $\mathrm{K}^{+}$channels}

At night, OXA-induced hyperpolarization persists even when AP-dependent synaptic communication and GABA-GABA $A_{A}$ receptor signaling are impaired (with TTX and gabazine, respectively), indicating that presynaptic mechanisms do not overtly contribute to these nocturnal inhibitory effects of OXA. To establish whether $\mathrm{Cl}^{-}$was involved in OXA's hyperpolarizing postsynaptic actions at night, we substituted gluconate for equimolar $\mathrm{Cl}^{-}$in the intracellular pipette solution in current-clamp recordings. This sets the reversal potential for $\mathrm{Cl}^{-}$near zero, eliminating $\mathrm{Cl}^{-}$conductances in these cells. Under this condition, the likely hyperpolarizing force capable of inhibiting the cells to this degree is produced by the $\mathrm{K}^{+}$channels. Indeed, recording with intracellular pipette solution containing $130 \mathrm{~mm} \mathrm{KCl} \mathrm{did} \mathrm{not}$ prevent the robust hyperpolarizing effects of OXA in all cells tested $(p>0.05$ for amplitude of hyperpolarization in $\mathrm{KCl}$ vs K-gluconate; $n=6$; Fig. $6 A$ ). This establishes that $\mathrm{K}^{+}$, but not $\mathrm{Cl}^{-}$, currents are responsible for this effect of orexin. OXAinduced hyperpolarization was also unaffected by fixing intracellular $\mathrm{Ca}^{2+}$ at $\sim 90 \mathrm{~nm}$ with a BAPTA-Ca ${ }^{2+}$ mixture $(n=5)$, or in the presence of a low $\mathrm{Ca}^{2+} /$ high $\mathrm{Mg}^{2+}$ aCSF $(n=7$; Fig. $6 B, C)$. Blockage of voltage-gated calcium channels with cadmium (30 $\mu \mathrm{M}$; Cloues and Sather, 2003; Pitts et al., 2006) also had no effect nine: control vs OXA, $p<0.01$; OXA vs OXA + quinine, $p<$ 0.01 ; quinidine: control vs OXA, $p<0.01$; OXA vs OXA + quinidine, $p<0.05$ ) and $R_{\text {input }}$ (post hoc tests for quinine: control vs OXA, $p<0.01$; OXA vs OXA + quinine, $p<0.01$; quinidine: control vs OXA, $p<0.05$; OXA vs OXA + quinidine, $p<0.05$ ) values to near baseline levels, causing some neurons to fire APs (Fig. $6 D, E$ ). This is consistent with the idea that leak $\mathrm{K}^{+}$channels are important for OXA's hyperpolarizing effects at night.

To define the nature of this leak $\mathrm{K}^{+}$current, we performed subsequent experiments in voltage-clamp recordings using slow ramps of voltage in the range from 0 to $-120 \mathrm{mV}$ (see Materials and Methods; Fig. $6 F$ ). In the presence of TTX (1-2 $\mu \mathrm{M})$, OXA $(80 \mathrm{nM})$ caused a change in the current-voltage relationship (Fig. $6 F$ ). The net current triggered by OXA (obtained by subtracting baseline $I-V$ from OXA $I-V$; Fig. $6 G$ ), had a reversal potential near $-93 \mathrm{mV}$ (expected $E_{k}=-102 \mathrm{mV}$ ), was almost linear, and was potently inhibited both by quinine $(n=11$; Fig. $6 G)$ and quinidine ( $n=5$; data not shown). Together, these observations implicate an OXA-activated current flowing through leak $\mathrm{K}^{+}$ channels to cause membrane inhibition. At night, Per1-EGFP neurons typically rest, on average, approximately $-47 \mathrm{mV}$ (Belle et al., 2009). At this voltage range (approximately $-47 \mathrm{mV}$ ), OXA significantly increased $\left(t_{(10)}=12.46 ; p<0.001\right.$, paired $t$ test $)$ the hyperpolarizing background leak $\mathrm{K}^{+}$conductance by $\sim 40 \%$ in 
responsive neurons (estimated by the size of the quinine-sensitive current). Therefore, activation of leak $\mathrm{K}^{+}$channels forms part of the mechanism by which OXA causes prolonged suppression in electrical activity of Per1-EGFP neurons at night.

\section{OXA modulates the acute and phase- resetting actions of NPY on SCN neurons}

Previous research has implicated inhibitory signaling as conveying arousalpromoting (or nonphotic) time cue information to the SCN (Smith et al., 1989; Cutler et al., 1998; Gribkoff et al., 1998). An important source of nonphotic input to the SCN is the GHT (Harrington, 1997) with NPY being an important signaling molecule in this pathway. During the day, NPY potently inhibits SCN neuronal activity, suppresses Per1 expression, and resets the SCN clock (Medanic and Gillette, 1993; Shibata and Moore, 1993; van den Pol et al., 1996; Fukuhara et al., 2001; Maywood et al., 2002). Since the predominant action of OXA on Per1-

EGFP SCN neurons is also suppression, we next asked whether daytime application of OXA phase advances the SCN molecular clock. We therefore assessed the phase of PER2::LUC rhythms in SCN brain slice cultures treated with OXA (80 nM), NPY (50 nM or $200 \mathrm{nM}$ ), or both in the middle of the circadian day (CT5). NPY at $200 \mathrm{~nm}$ evoked large $(\sim 6 \mathrm{~h})$ phase advances in the timing of peak PER2::LUC expression, which were significantly different to the effects of control protocols $\left(t_{(6)}=2.89, p<0.05\right.$; Fig. $\left.7 A\right)$. Low-dose NPY (50 nM) or OXA ( $80 \mathrm{~nm})$ alone did not alter the timing of peak PER2::LUC (net shift relative to controls of $\sim 0.9 \mathrm{~h}$ and approximately $-0.2 \mathrm{~h}$, respectively; both $p>0.05)$. However, coapplication of OXA (80 nM) and NPY (50 nM) induced phase advances $(\sim 2 \mathrm{~h})$ that were significantly larger than those measured with NPY alone $\left(F_{(1,53)}=4.1, p<0.05\right)$ or in controls $\left(F_{(1,53)}=10.1, p<0.01\right.$; Fig. $\left.7 B, C\right)$. This indicates that OXA signaling in the SCN enhances the phase-shifting capacity of NPY on core molecular clock rhythms. Further, this shows that although OXA on its own modulates the electrical activity and intracellular $\mathrm{Ca}^{2+}$ of the majority of SCN neurons tested over the day, this neuropeptide does not itself evoke measurable phase shifts of the SCN.

Nonphotic stimuli have much less prominent phase-shifting effects during the subjective night, and to test whether these resetting actions of OXA and NPY also show phase dependence, we assessed shifts in PER2::LUC expression following treatments with OXA ( $80 \mathrm{~nm}$ ), NPY (50 nM), or OXA and NPY given at the middle of the projected night (CT17). Neither neuropeptide alone nor in combination produced phase advances; indeed, only nonsignificant small phase delays were observed (Fig. $7 B$ ). This indicates that although OXA has long-lasting suppressive effects on electrical activity and intracellular $\mathrm{Ca}^{2+}$ of SCN neurons at night, these acute effects do not detectably influence the phase of the SCN molecular clock during the circadian night. Collectively, these data demonstrate that during the subjective day, OXA significantly augments the phase-resetting actions of a subthreshold dose of NPY, while at night, neither neuropeptide alone or in combination can significantly reset the SCN clock.
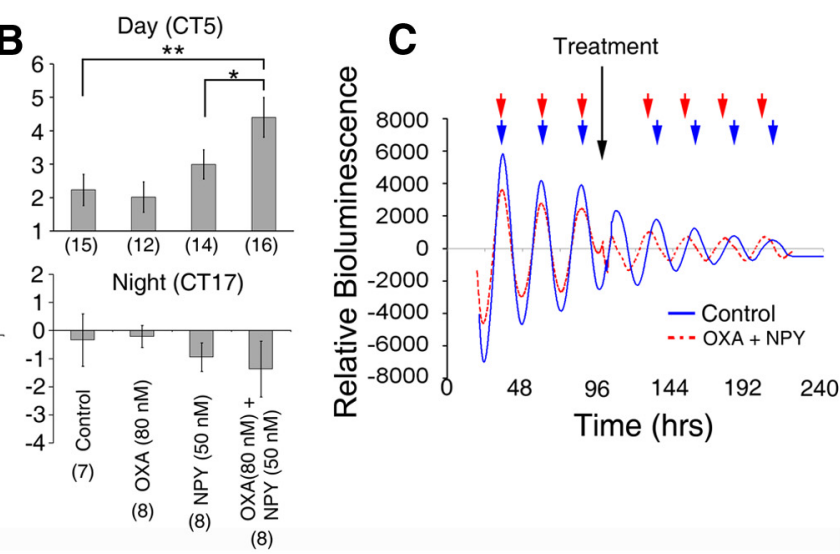

Figure 7. OXA augments NPY's phase-shifting capacity of SCN clock neurons. $\boldsymbol{A}$, During the day NPY (200 nm) significantly projected or night. OXA and NPY combined, however, result in significant phase advances during the day, but not at $<0.01$ denote significance ( $t$ test or ANOVA with a priori pairwise comparison). Number of brain slices used for each condition are shown in parentheses. Data shown in $\boldsymbol{A}$ and $\boldsymbol{B}$ are mean $\pm \mathrm{SEM}$.

Since OXA enhanced the daytime resetting actions of NPY, we next investigated whether OXA influences the inhibitory actions of NPY on SCN neurons. We performed targeted current-clamp recordings from SCN Per1-EGFP cells in the day and compared their responses to NPY (two $40 \mathrm{~nm}$ brief applications by puffer pipette) both alone and in the presence of bath-applied OXA ( 80 $\mathrm{nM}$ ). To allow for appropriate comparison between NPY's actions alone and in the presence of bath-applied OXA, the following recording and drug treatment procedures were used (Fig. $8 A)$. First, the cell's response to two consecutive brief focal applications of NPY (40 nM) was tested, allowing for full recovery of the cell's RMP between NPY applications. OXA was then bath applied until the cell's response to this neuropeptide reached maximal value and plateaued. Next, before the cell's response to NPY was retested in the presence of OXA, the RMP of the neuron was returned to its initial baseline value (before OXA application) by manually passing a steady-state current (e.g., indicated by a + ve current in Fig. 8A). This ensures that most of the membrane's ionic conditions are restored to baseline values, allowing for appropriate comparisons with previous NPY applications (when OXA was not present). This steady-state current injection was applied in conjunction with the puffer application of NPY and removed only following the full recovery of the cells to NPY (Fig. 8A). Electrical recordings from SCN Per1-EGFP cells that showed sensitivity both to OXA and NPY (15 of 34 neurons tested) revealed that the suppressive actions of NPY ( $40 \mathrm{nM}$ ) on these cells were significantly larger in the presence of OXA (80 nM; $n=15$; Fig. $8 A, B)$. Both the amplitude (NPY $=\Delta 3.9 \pm 0.5$ $\left.\mathrm{mV} ; \mathrm{NPY}+\mathrm{OXA}=\Delta 8.5 \pm 1.3 \mathrm{mV} ; t_{(14)}=-3.34, p<0.01\right)$ and duration $(\mathrm{NPY}=\Delta 1.3 \pm 0.2 \mathrm{~s}$; NPY $+\mathrm{OXA}=\Delta 13.3 \pm 2.7 \mathrm{~s}$; $\left.t_{(14)}=-4.33, p<0.01\right)$ of NPY-induced membrane hyperpolarization significantly increased in the presence of OXA compared with NPY alone (Fig. $8 A, B$ ). Similar observations were seen in 5 of the 19 cells that showed no overt responsiveness to OXA (data not shown).

We next investigated if $\mathrm{GABA}-\mathrm{GABA}_{\mathrm{A}}$ receptor signaling is recruited by OXA to potentiate these acute actions of NPY on 


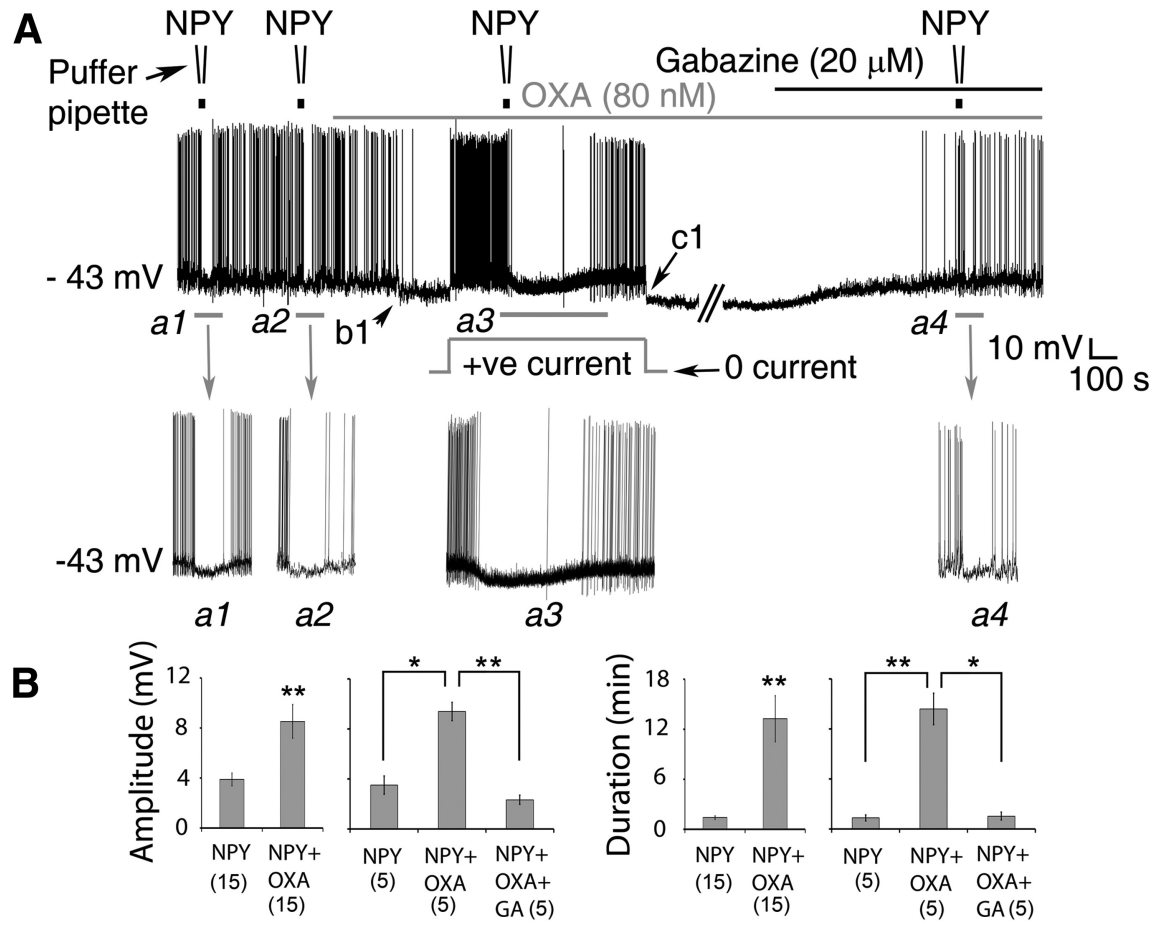

Figure 8. OXA enhances NPY's suppression of the electrical activity of SCN clock neurons. $\boldsymbol{A}$, Representative whole-cell recording from a Per1-EGFP neuron showing hyperpolarizing responses to focally applied NPY (40 nm) and bath-applied OXA ( $80 \mathrm{nm).} \mathrm{In} \mathrm{the}$ basal condition, responses of the cell to NPY were tested twice (Inset $\boldsymbol{a} 1, \boldsymbol{a} 2)$ to assess reproducibility of its hyperpolarizing effects. In this particular neuron, $30 \mathrm{~s}$ NPY puffs elicited $<1$ min suppression in each trial. OXA was then continuously bath applied (top gray bar). OXA's effect can be seen from $\boldsymbol{b} 1$ with a clear hyperpolarization of the RMP of the cell and inhibition of APs. Before testing the cell's response to NPY in the presence of OXA, a positive steady-state current was applied (indicated by the gray square hump) when OXA's hyperpolarizing response plateaued. Notice that the cell resumed AP firing when its RMP was returned to the basal value of $-43 \mathrm{mV}$. In the presence of OXA, the amplitude and duration of RMP suppression by NPY were significantly increased $(\boldsymbol{a} \mathbf{3})$ when compared with NPY alone (compare $\boldsymbol{a} 3$ with $\boldsymbol{a} \mathbf{1}$ and $\boldsymbol{a}$ 2). $\mathbf{c 1}$, After recovery from NPY treatment, the steady-state positive current was removed. To test whether $\mathrm{GABA}_{\mathrm{A}}$ receptors are involved, gabazine ( $20 \mu \mathrm{m}$; black bar on top of gray bar) was then coapplied with OXA. Note that blockade of $\mathrm{GABA}_{\mathrm{A}}$ receptors with gabazine counteracts OXA-hyperpolarizing effects (as in Fig. $4 F$ ), reverting the cell's RMP to control value (approximately $-43 \mathrm{mV}$ ). In the presence of $0 X A$ and gabazine, the hyperpolarizing effect of NPY ( $\boldsymbol{a} 4)$ was similar to controls $(\boldsymbol{a} 1, \boldsymbol{a} 2)$. $\boldsymbol{B}$, Summary of results (amplitude and duration) from Per1-EGFP neurons tested over the day with NPY followed by OXA + NPY $(n=15)$, or NPY followed by OXA + NPY and OXA + NPY + gabazine $(n=5)$ over the day. ${ }^{*} p<0.05,{ }^{* *} p<0.01$ denotes significance (one-way ANOVA, Sidak with repeated measures or paired $t$ test). Data are expressed as mean \pm SEM. Number of cells measured is shown in parentheses.

SCN neurons. To do this, we first tested the cell's response to NPY alone, then to NPY and OXA, as described above. But in addition, to see if $\mathrm{GABA}_{\mathrm{A}}$ receptor blockade prevents OXA's facilitation of NPY's suppressive action, we also tested the effect of NPY in the presence of bath coapplication of gabazine and OXA. Indeed, as shown in Figure $8, A$ and $B\left(n=5\right.$ cells), blockade of $\mathrm{GABA}_{\mathrm{A}}$ receptors with gabazine abolished the potentiating effect of OXA on NPY's inhibitory action on Per1-EGFP neurons (hyperpolarization amplitude: NPY alone vs NPY + OXA vs NPY + OXA + Gabazine, $F_{(2,8)}=34.93, p<0.001$; duration: NPY alone vs NPY + OXA vs NPY + OXA + Gabazine, $F_{(2,8)}=40.38, p<0.001$; see Fig. $8 B$ for illustration of group mean comparisons). Together, these results demonstrate that in the SCN OXA acts via GABA$\mathrm{GABA}_{\mathrm{A}}$ receptor signaling to facilitate the phase-shifting and electrical silencing capacity of NPY.

\section{Discussion}

Here we show a new atypical influence of orexin signaling over SCN clock cell activity and timekeeping. Physiological investigations in vitro demonstrate clear day-night differences in the polarity of SCN neuronal responses to orexin. Across the projected circadian cycle, most orexin-responsive SCN neurons respond to orexin by suppressing baseline intracellular calcium levels $\left(\left[\mathrm{Ca}^{2+}\right]_{\mathrm{i}}\right)$ and neuronal activity. Actions of this neuropeptide are prevented by blockade of orexin receptors, but local inhibitory circuits within the SCN are differentially recruited by orexin from day to night. During the day, orexin presynaptically modulates inhibitory $\mathrm{GABA}_{-\mathrm{GABA}}$ receptor signaling, while at night, orexin's suppressive actions do not require recruitment of either $\mathrm{GABA}_{-\mathrm{GABA}_{\mathrm{A}} \text { or GABA-GABA }}$ receptor signaling mechanisms. Instead, these nighttime inhibitions to orexin arise through direct postsynaptic activation of leak $\mathrm{K}^{+}$currents and hyperpolarization of SCN neurons. Functionally, orexin enhanced the phase-advancing actions of NPY, another neuropeptide implicated in conveying arousal information to the SCN. This modulation of peptidergic signaling is observable at the single neuron level where orexin potentiates inhibitory effects of NPY during the day. Thus, orexin in the SCN is mostly inhibitory and functions like other neural signals implicated in relaying arousal information to the SCN clock.

Direct orexin signaling in the brain is commonly considered excitatory (Eriksson et al., 2010) and can elicit depolarization, increased AP firing, and elevations in $\left[\mathrm{Ca}^{2+}\right]_{\mathrm{i}}$. However, in the SCN, these actions of orexin were rarely observed, especially at night. Even during the day, direct excitatory actions of orexin on $\left[\mathrm{Ca}^{2+}\right]_{i}$ and Per1-EGFP neuronal activity were observed in only a minority of OXAresponsive cells, whereas most OXAresponsive Per1-EGFP neurons in the SCN were indirectly inhibited by OXA. Since the majority of SCN neurons are GABAergic (Antle and Silver, 2005), this indicates a possible pathway through which orexin excitation of some SCN neurons increases inhibitory GABAergic tone within the SCN overall.

In other parts of the hypothalamus and brainstem, orexin excites local GABAergic interneurons to presynaptically regulate GABAergic transmission (van den Pol et al., 1998; Liu et al., 2002; Eriksson et al., 2004; Ma et al., 2007). In our daytime SCN recordings, focal application of gabazine into the SCN blocked orexin's suppression of the Perl-EGFP neurons, thereby showing that orexin can increase the frequency of GABA-mediated IPSCs, presumably by increasing GABA release from local SCN neurons. Indeed, across the projected day, we found that orexin evoked increases in $\mathrm{GABA}_{\mathrm{A}}$ receptor-mediated inhibitory events both in an impulse-dependent and independent manner with gabazine preventing orexin from reducing $\left[\mathrm{Ca}^{2+}\right]_{\mathrm{i}}$. These observations are consistent with rat SCN recordings, where orexin increased GABAergic neurotransmission in unidentified SCN neurons (Klisch et al., 2009). In addition, we found that OXA increased the amplitude of these GABAergic IPSCs, an observation consistent with findings of orexin's actions in the nucleus ambiguus (Dergacheva et al., 2011). This indicates that during the day, OXA 
A

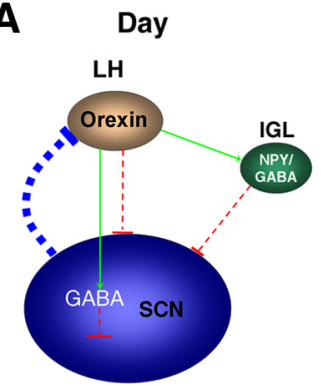

B

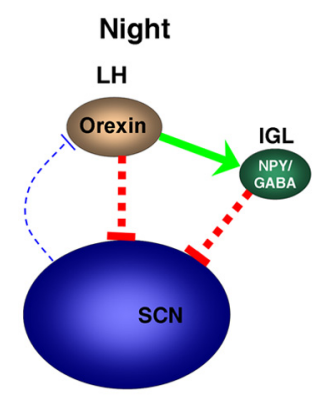

C Daytime Arousal

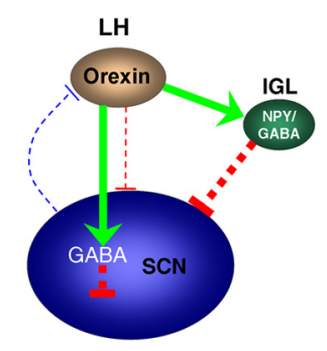

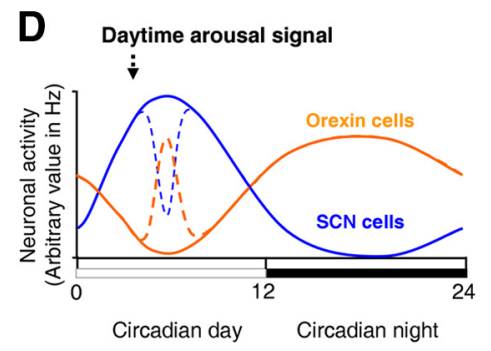

Figure 9. Schematic diagram summarizing SCN cellular responses to circadian and arousalpromoting cues in nocturnal rodents. $\boldsymbol{A}$, Throughout the subjective day, electrical activity and inhibitory output from the SCN is high (thick blue line), with orexinergic cells in the lateral hypothalamus (LH) minimally active, providing nominal/no presynaptic signal (green arrow) to liberate GABA in the SCN to suppress activity of Per1-EGFP neurons. At this circadian phase, the inhibitory signal from IGL-NPY cells to the SCN is also at a nadir (thin red line) due to low/no orexinergic excitatory signal (thin green arrow) to the IGL. B, During the night, electrical activity and inhibitory output from the SCN is low (thin blue line), with orexinergic cells showing elevated electrical activity, providing strong excitatory input to IGL-NPY cells (thick green arrow) and large postsynaptic direct inhibitory input to SCN Per1-EGFP cells (thick red line). C, During daytime, arousal-promoting stimuli activate orexin cells, providing increased orexinergic signaling to the SCN (thick green line). This initially elevates GABA release in the SCN which then suppresses SCN electrical activity. Increased orexinergic signaling also activates IGL-NPY cells (thick green arrow), which also provides further suppressive signal to the SCN (thick red line). In the SCN, orexin facilitates NPY's inhibitory actions by enhancing GABA signaling. The width of the arrows (excitatory signal) and T-bars (inhibitory signal) indicates the level of excitation or inhibition, respectively. D, Circadian variation in SCN (blue line) and orexin (orange line) cellular activity, and the effects of daytime arousal-promoting stimuli on this activation (broken lines; Marston et al., 2008; van 0osterhout et al., 2012).

enhances release of GABA in the SCN, triggering robust GABA$\mathrm{GABA}_{\mathrm{A}}$ receptor-mediated suppression of SCN electrical activity and $\left[\mathrm{Ca}^{2+}\right]_{\mathrm{i}}$ (Fig. 9).

In stark contrast, orexin's inhibitory actions at night are independent of GABAergic signaling, and instead arise through orexin acting directly to activate background leak $\mathrm{K}^{+}$currents (Figs. 6, 9). These leak channels are important for determining and maintaining resting membrane potential and excitability in cells (Mathie, 2007), and expression of their gene transcripts (Lein et al., 2007) and their physiological activity (Wang et al., 2012) are reported in the SCN. Here we show that activation of leak $\mathrm{K}^{+}$currents by orexin at night produces robust inhibition of electrical activity in SCN neurons. To our knowledge, this is the first description of a direct hyperpolarizing action of orexin in the brain. Importantly, orexin-mediated inhibition of the SCN during the night (when orexin neuronal activation and signaling are maximal; Deboer et al., 2004; Zhang et al., 2004) may therefore serve to reinforce the intrinsic rhythm in SCN electrical activity (Fig. 9). This helps to explain the paradox that orexin neuronal activity and orexin release are high when SCN neuronal activity, intracellular calcium levels, and Per gene expression are low.
Elsewhere in the brain, orexin depolarizes neurons by inhibiting $\mathrm{K}^{+}$conductances, including leak $\mathrm{K}^{+}$currents (Ivanov and Aston-Jones, 2000; Govindaiah and Cox, 2006), activation of nonspecific cation channels (Liu et al., 2002; Yang and Ferguson, 2003), or by activating the $\mathrm{Na}^{+} / \mathrm{Ca}^{2+}$ exchanger (Burdakov et al., 2003). One possible explanation for the apparent novelty of our findings is that most interrogations of orexin's actions are performed during the day on tissue from nocturnal rodents. Another study of the nocturnal actions of orexin found that in preoptic and anterior hypothalamic GnRH neurons, orexin profoundly suppresses electrical activity in these cells at night (Gaskins and Moenter, 2012). Hence, clear day-night differences in the responses and mechanisms of orexin's actions in the CNS may be widespread.

The precise contribution of $\mathrm{OX}_{1}$ and $\mathrm{OX}_{2}$ receptors to these complex actions of orexin in the SCN remains to be fully elucidated. The observation that $O X_{1}$ expression is elevated at dusk, in line with Per 2 expression, suggests that the molecular clock could increase orexin receptor availability at night. Orexin receptors are promiscuous and can couple both to excitatory and/or inhibitory G-proteins (Karteris and Randeva, 2003). Since transcripts for both receptor types are expressed in the SCN, the balance between inhibitory and excitatory actions of OXA could be dictated by clock-regulated changes in the G-proteins to which the native orexin receptors in the $\mathrm{SCN}$ are coupled and/or by the differential expression of $\mathrm{OX}_{1}$ and $\mathrm{OX}_{2}$ (Scammell and Winrow, 2011).

During the day, the circadian rhythms in the SCN clock and in behavior can be reset by so-called nonphotic/arousal-promoting stimuli (Mistlberger and Antle, 2011; Hughes and Piggins, 2012). NPY conveys nonphotic information to the SCN and it is notable in this study that OXA enhanced the inhibitory actions of NPY on single Per1-EGFP SCN cells as well as augmented its phaseshifting effects on the SCN molecular clock during the day. Intriguingly, arousal-promoting stimuli that reset circadian rhythms in behavior activate lateral hypothalamic orexin neurons (Marston et al., 2008; Webb et al., 2008). Orexin neurons innervate the IGL (Peyron et al., 1998; McGranaghan and Piggins, 2001; Mintz et al., 2001; Nixon and Smale, 2005), the source of the NPY innervation of the SCN, and orexin modulates the activity of IGL cells in vitro (Pekala et al., 2011). Nonphotic resetting is associated with suppression of SCN cellular activity and of clock gene expression (Maywood et al., 2002) including Per1 (Hamada et al., 2004). Collectively, our results and those of others now implicate orexin signaling in the integration of nonphotic information within the SCN.

This suggests that the indirect daytime inhibitory actions of orexin play a more prominent role in regulating clock phase than its direct excitatory actions at this time. Further, as orexin is inhibitory at night and as neither orexin nor other inhibitory stimuli appear to reset the SCN clock at this time (Brown and Piggins, 2007), this shows that the orexin's potential roles in the SCN vary from day to night. Indeed, the suppressive actions of orexin at night could act as feedback from aroused behavioral states to reinforce the molecular clock's inhibition of SCN neuronal activity (Fig. 9). This suppressive orexinergic signal may be integral to the Zeitnehmer cues involved with SCN clock entrainment processes (Hughes and Piggins, 2012; Roenneberg et al., 2013).

Despite the ability of orexin to inhibit daytime electrical activity within the SCN, this neuropeptide (on its own) was ineffective at shifting the circadian clockwork. This is an important observation, in that it indicates that orexin signaling is capable of alleviating SCN inhibition of behavioral activity in an acute manner, 
which does not have lasting impact on circadian rhythmicity overall. This is especially important in a natural setting where animals must respond to short-term alterations in the environment, yet do not want to uncouple overall behavioral rhythmicity (SCN clock controlled) from prevailing light-dark cycles. This type of paradigm is well studied, for example, during daytime restricted feeding of nocturnal rodents (Mistlberger and Antle, 2011). It is noteworthy that mice deficient in orexin signaling have impaired circadian control of wake and some sleep states (Mochizuki et al., 2004) and have reduced anticipatory responses to restricted feeding (Akiyama et al., 2004).

In summary, our findings establish that orexin signaling in the $\mathrm{SCN}$ is mostly inhibitory and relies on intrinsic circadian clockcontrolled membrane properties and neurochemistry of SCN cells to produce its effects on SCN $\left[\mathrm{Ca}^{2+}\right]_{\mathrm{i}}$ and electrical activity. Here, we also show that orexin acts in the SCN to modulate the way the master circadian clock responds to other key arousal inputs. These findings support the view that in vertebrates, orexin signaling plays pivotal roles in the timing of transitions in brain and behavioral states (Mochizuki et al., 2004; Elbaz et al., 2012). Since the neural circadian system is extensive (Sakhi et al., 2013) and because orexin neurons innervate many components of this circadian timing circuitry (Peyron et al., 1998), it is important to understand how orexin signaling integrates with circadian time cues to influence neuronal activity in these areas. A key implication is that the mechanisms of orexin's actions in the SCN switch from predominantly GABA-mediated presynaptic actions during the day to robust direct postsynaptic effects at night.

\section{References}

Akiyama M, Yuasa T, Hayasaka N, Horikawa K, Sakurai T, Shibata S (2004) Reduced food anticipatory activity in genetically orexin (hypocretin) neuron-ablated mice. Eur J Neurosci 20:3054-3062. CrossRef Medline

Antle MC, Silver R (2005) Orchestrating time: arrangements of the brain circadian clock. Trends Neurosci 28:145-151. CrossRef Medline

Bäckberg M, Hervieu G, Wilson S, Meister B (2002) Orexin receptor-1 (OX-R1) immunoreactivity in chemically identified neurons of the hypothalamus: focus on orexin targets involved in control of food and water intake. Eur J Neurosci 15:315-328. CrossRef Medline

Belle MD, Diekman CO, Forger DB, Piggins HD (2009) Daily electrical silencing in the mammalian circadian clock. Science 326:281-284. CrossRef Medline

Briston SJ, Caldwell JL, Horn MA, Clarke JD, Richards MA, Greensmith DJ, Graham HK, Hall MC, Eisner DA, Dibb KM, Trafford AW (2011) Impaired beta-adrenergic responsiveness accentuates dysfunctional excitationcontraction coupling in an ovine model of tachypacing-induced heart failure. J Physiol 589:1367-1382. CrossRef Medline

Brown TM, Piggins HD (2007) Electrophysiology of the suprachiasmatic circadian clock. Prog Neurobiol 82:229-255. CrossRef Medline

Brown TM, Coogan AN, Cutler DJ, Hughes AT, Piggins HD (2008) Electrophysiological actions of orexins on rat suprachiasmatic neurons in vitro. Neurosci Lett 448:273-278. CrossRef Medline

Buijs RM, Hou YX, Shinn S, Renaud LP (1994) Ultrastructural evidence for intra- and extranuclear projections of GABAergic neurons of the suprachiasmatic nucleus. J Comp Neurol 340:381-391. CrossRef Medline

Burdakov D, Liss B, Ashcroft FM (2003) Orexin excites GABAergic neurons of the arcuate nucleus by activating the sodium-calcium exchanger. J Neurosci 23:4951-4957. Medline

Burdakov D, Jensen LT, Alexopoulos H, Williams RH, Fearon IM, O'Kelly I, Gerasimenko O, Fugger L, Verkhratsky A (2006) Tandem-pore K+ channels mediate inhibition of orexin neurons by glucose. Neuron 50 : 711-722. CrossRef Medline

Castel M, Morris JF (2000) Morphological heterogeneity of the GABAergic network in the suprachiasmatic nucleus, the brain's circadian pacemaker. J Anat 196:1-13. CrossRef Medline

Chemelli RM, Willie JT, Sinton CM, Elmquist JK, Scammell T, Lee C, Richardson JA, Williams SC, Xiong Y, Kisanuki Y, Fitch TE, Nakazato M, Hammer RE, Saper CB, Yanagisawa M (1999) Narcolepsy in orexin knockout mice: molecular genetics of sleep regulation. Cell 98:437-451. CrossRef Medline

Cloues RK, Sather WA (2003) Afterhyperpolarization regulates firing rate in neurons of the suprachiasmatic nucleus. J Neurosci 23:1593-1604. Medline

Colwell CS (2000) Circadian modulation of calcium levels in cells in the suprachiasmatic nucleus. Eur J Neurosci 12:571-576. CrossRef Medline

Colwell CS (2011) Linking neural activity and molecular oscillations in the SCN. Nat Rev Neurosci 12:553-569. CrossRef Medline

Cutler DJ, Piggins HD, Selbie LA, Mason R (1998) Responses to neuropeptide $\mathrm{Y}$ in adult hamster suprachiasmatic nucleus neurones in vitro. Eur J Pharmacol 345:155-162. CrossRef Medline

Deboer T, Overeem S, Visser NA, Duindam H, Frölich M, Lammers GJ, Meijer JH (2004) Convergence of circadian and sleep regulatory mechanisms on hypocretin-1. Neuroscience 129:727-732. CrossRef Medline

Dergacheva O, Philbin K, Bateman R, Mendelowitz D (2011) Hypocretin-1 (orexin A) prevents the effects of hypoxia/hypercapnia and enhances the GABAergic pathway from the lateral paragigantocellular nucleus to cardiac vagal neurons in the nucleus ambiguus. Neuroscience 175:18-23. CrossRef Medline

Diekman CO, Belle MD, Irwin RP, Allen CN, Piggins HD, Forger DB (2013) Causes and consequences of hyperexcitation in central clock neurons. PLoS Comput Biol 9:e1003196. CrossRef Medline

Elbaz I, Yelin-Bekerman L, Nicenboim J, Vatine G, Appelbaum L (2012) Genetic ablation of hypocretin neurons alters behavioral state transitions in zebrafish. J Neurosci 32:12961-12972. CrossRef Medline

Eriksson KS, Sergeeva OA, Selbach O, Haas HL (2004) Orexin (hypocretin)/ dynorphin neurons control GABAergic inputs to tuberomammillary neurons. Eur J Neurosci 19:1278-1284. CrossRef Medline

Eriksson KS, Sergeeva OA, Haas HL, Selbach O (2010) Orexins/hypocretins and aminergic systems. Acta Physiol 198:263-275. CrossRef

Estabrooke IV, McCarthy MT, Ko E, Chou TC, Chemelli RM, Yanagisawa M, Saper CB, Scammell TE (2001) Fos expression in orexin neurons varies with behavioral state. J Neurosci 21:1656-1662. Medline

Francois-Bellan AM, Hery M, Faudon M, Hery F (1989) Analysis of the inhibitory effect of oestradiol on functional GABA/5-HT relationship in the rat suprachiasmatic area. J Neuroendocrinol 1:415-422. CrossRef Medline

Fukuhara C, Brewer JM, Dirden JC, Bittman EL, Tosini G, Harrington ME (2001) Neuropeptide Y rapidly reduces Period 1 and Period 2 mRNA levels in the hamster suprachiasmatic nucleus. Neurosci Lett 314:119122. CrossRef Medline

Gaskins GT, Moenter SM (2012) Orexin a suppresses gonadotropinreleasing hormone $(\mathrm{GnRH})$ neuron activity in the mouse. Endocrinology 153:3850-3860. CrossRef Medline

Gillette MU, Medanic M, McArthur AJ, Liu C, Ding JM, Faiman LE, Weber ET, Tcheng TK, Gallman EA (1995) Intrinsic neuronal rhythms in the suprachiasmatic nuclei and their adjustment. Ciba Found Symp 183:134144; discussion 144-153. Medline

Govindaiah G, Cox CL (2006) Modulation of thalamic neuron excitability by orexins. Neuropharmacology 51:414-425. CrossRef Medline

Gribkoff VK, Pieschl RL, Wisialowski TA, van den Pol AN, Yocca FD (1998) Phase shifting of circadian rhythms and depression of neuronal activity in the rat suprachiasmatic nucleus by neuropeptide $\mathrm{Y}$ : mediation by different receptor subtypes. J Neurosci 18:3014-3022. Medline

Gribkoff VK, Pieschl RL, Dudek FE (2003) GABA receptor-mediated inhibition of neuronal activity in rat SCN in vitro: pharmacology and influence of circadian phase. J Neurophysiol 90:1438-1448. CrossRef Medline

Guilding C, Hughes AT, Brown TM, Namvar S, Piggins HD (2009) A riot of rhythms: neuronal and glial circadian oscillators in the mediobasal hypothalamus. Mol Brain 2:28. CrossRef Medline

Hamada T, Antle MC, Silver R (2004) The role of Period1 in non-photic resetting of the hamster circadian pacemaker in the suprachiasmatic nucleus. Neurosci Lett 362:87-90. CrossRef Medline

Harrington ME (1997) The ventral lateral geniculate nucleus and the intergeniculate leaflet: interrelated structures in the visual and circadian systems. Neurosci Biobehav Rev 21:705-727. CrossRef Medline

Hughes AT, Piggins HD (2012) Feedback actions of locomotor activity to the circadian clock. Prog Brain Res 199:305-336. CrossRef Medline

Hughes AT, Guilding C, Lennox L, Samuels RE, McMahon DG, Piggins HD (2008) Live imaging of altered period 1 expression in the suprachiasmatic nuclei of Vipr2-/- mice. J Neurochem 106:1646-1657. CrossRef Medline 
Hughes AT, Guilding C, Piggins HD (2011) Neuropeptide signaling differentially affects phase maintenance and rhythm generation in SCN and extra-SCN circadian oscillators. PLoS One 6:e18926. CrossRef Medline

Ikeda M (2004) Calcium dynamics and circadian rhythms in suprachiasmatic nucleus neurons. Neuroscientist 10:315-324. CrossRef Medline

Ikeda M, Sugiyama T, Wallace CS, Gompf HS, Yoshioka T, Miyawaki A, Allen CN (2003) Circadian dynamics of cytosolic and nuclear Ca2+ in single suprachiasmatic nucleus neurons. Neuron 38:253-263. CrossRef Medline

Irwin RP, Allen CN (2007) Calcium response to retinohypothalamic tract synaptic transmission in suprachiasmatic nucleus neurons. J Neurosci 27:11748-11757. CrossRef Medline

Irwin RP, Allen CN (2009) GABAergic signaling induces divergent neuronal Ca2 + responses in the suprachiasmatic nucleus network. Eur J Neurosci 30:1462-1475. CrossRef Medline

Irwin RP, Allen CN (2010) Neuropeptide-mediated calcium signaling in the suprachiasmatic nucleus network. Eur J Neurosci 32:1497-1506. CrossRef Medline

Itri J, Colwell CS (2003) Regulation of inhibitory synaptic transmission by vasoactive intestinal peptide (VIP) in the mouse suprachiasmatic nucleus. J Neurophysiol 90:1589-1597. CrossRef Medline

Itri J, Michel S, Waschek JA, Colwell CS (2004) Circadian rhythm in inhibitory synaptic transmission in the mouse suprachiasmatic nucleus. J Neurophysiol 92:311-319. CrossRef Medline

Ivanov A, Aston-Jones G (2000) Hypocretin/orexin depolarizes and decreases potassium conductance in locus coeruleus neurons. Neuroreport 11:1755-1758. CrossRef Medline

Jackson AC, Yao GL, Bean BP (2004) Mechanism of spontaneous firing in dorsomedial suprachiasmatic nucleus neurons. J Neurosci 24:7985-7998. CrossRef Medline

Karteris E, Randeva HS (2003) Orexin receptors and G-protein coupling: evidence for another "promiscuous" seven transmembrane domain receptor. J Pharmacol Sci 93:126-128. CrossRef Medline

Klisch C, Inyushkin A, Mordel J, Karnas D, Pévet P, Meissl H (2009) Orexin A modulates neuronal activity of the rodent suprachiasmatic nucleus in vitro. Eur J Neurosci 30:65-75. CrossRef Medline

Kohlmeier KA, Watanabe S, Tyler CJ, Burlet S, Leonard CS (2008) Dual orexin actions on dorsal raphe and laterodorsal tegmentum neurons: noisy cation current activation and selective enhancement of Ca2 + transients mediated by L-type calcium channels. J Neurophysiol 100:22652281. CrossRef Medline

Kuhlman SJ, Quintero JE, McMahon DG (2000) GFP fluorescence reports Period 1 circadian gene regulation in the mammalian biological clock. Neuroreport 11:1479-1482. CrossRef Medline

Kuhlman SJ, Silver R, Le Sauter J, Bult-Ito A, McMahon DG (2003) Phase resetting light pulses induce Per1 and persistent spike activity in a subpopulation of biological clock neurons. J Neurosci 23:1441-1450. Medline

Kukkonen JP (2013) Physiology of the orexinergic/hypocretinergic system: a revisit in 2012. Am J Physiol Cell Physiol 304:C2-C32. CrossRef Medline

Kukkonen JP, Akerman KEO (2005) Intracellular signal pathways utilized by the hypocretin/orexin receptors. In: Hypocretins: integrators of physiological signals (de Lecea L, Sutcliffe JG, eds), pp 221-231. Berlin: Springer Science Business Media.

Lein ES, Hawrylycz MJ, Ao N, Ayres M, Bensinger A, Bernard A, Boe AF, Boguski MS, Brockway KS, Byrnes EJ, Chen L, Chen L, Chen TM, Chin MC, Chong J, Crook BE, Czaplinska A, Dang CN, Datta S, Dee NR, et al. (2007) Genome-wide atlas of gene expression in the adult mouse brain. Nature 445:168-176. CrossRef Medline

Li JD, Hu WP, Zhou QY (2012) The circadian output signals from the suprachiasmatic nuclei. Prog Brain Res 199:119-127. CrossRef Medline

Liu RJ, van den Pol AN, Aghajanian GK (2002) Hypocretins (orexins) regulate serotonin neurons in the dorsal raphe nucleus by excitatory direct and inhibitory indirect actions. J Neurosci 22:9453-9464. Medline

Lotshaw DP (2007) Biophysical, pharmacological, and functional characteristics of cloned and native mammalian two-pore domain $\mathrm{K}+$ channels. Cell Biochem Biophys 47:209-256. CrossRef Medline

Ma X, Zubcevic L, Brüning JC, Ashcroft FM, Burdakov D (2007) Electrical inhibition of identified anorexigenic POMC neurons by orexin/hypocretin. J Neurosci 27:1529-1533. CrossRef Medline

Marston OJ, Williams RH, Canal MM, Samuels RE, Upton N, Piggins HD (2008) Circadian and dark-pulse activation of orexin/hypocretin neurons. Mol Brain 1:19. CrossRef Medline
Mathie A (2007) Neuronal two-pore-domain potassium channels and their regulation by $\mathrm{G}$ protein-coupled receptors. J Physiol 578:377-385. Medline

Maywood ES, Okamura H, Hastings MH (2002) Opposing actions of neuropeptide $\mathrm{Y}$ and light on the expression of circadian clock genes in the mouse suprachiasmatic nuclei. Eur J Neurosci 15:216-220. CrossRef Medline

McGranaghan PA, Piggins HD (2001) Orexin A-like immunoreactivity in the hypothalamus and thalamus of the Syrian hamster (Mesocricetus auratus) and Siberian hamster (Phodopus sungorus), with special reference to circadian structures. Brain Res 904:234-244. CrossRef Medline

Medanic M, Gillette MU (1993) Suprachiasmatic circadian pacemaker of rat shows two windows of sensitivity to neuropeptide $\mathrm{Y}$ in vitro. Brain Res 620:281-286. CrossRef Medline

Mintz EM, van den Pol AN, Casano AA, Albers HE (2001) Distribution of hypocretin-(orexin) immunoreactivity in the central nervous system of Syrian hamsters (Mesocricetus auratus). J Chem Neuroanat 21:225-238. CrossRef Medline

Mistlberger RE, Antle MC (2011) Entrainment of circadian clocks in mammals by arousal and food. Essays Biochem 49:119-136. CrossRef Medline

Mochizuki T, Crocker A, McCormack S, Yanagisawa M, Sakurai T, Scammell TE (2004) Behavioral state instability in orexin knock-out mice. J Neurosci 24:6291-6300. CrossRef Medline

Moldavan MG, Irwin RP, Allen CN (2006) Presynaptic GABA(B) receptors regulate retinohypothalamic tract synaptic transmission by inhibiting voltage-gated Ca2+ channels. J Neurophysiol 95:3727-3741. CrossRef Medline

Moore RY, Speh JC (1993) GABA is the principal neurotransmitter of the circadian system. Neurosci Lett 150:112-116. CrossRef Medline

Nambu T, Sakurai T, Mizukami K, Hosoya Y, Yanagisawa M, Goto K (1999) Distribution of orexin neurons in the adult rat brain. Brain Res 827:243260. CrossRef Medline

Nixon JP, Smale L (2005) Orexin fibers form appositions with Fos expressing neuropeptide-Y cells in the grass rat intergeniculate leaflet. Brain Res 1053:33-37. CrossRef Medline

Pekala D, Blasiak T, Raastad M, Lewandowski MH (2011) The influence of orexins on the firing rate and pattern of rat intergeniculate leaflet neurons-electrophysiological and immunohistological studies. Eur J Neurosci 34:1406-1418. CrossRef Medline

Peyron C, Tighe DK, van den Pol AN, de Lecea L, Heller HC, Sutcliffe JG, Kilduff TS (1998) Neurons containing hypocretin (orexin) project to multiple neuronal systems. J Neurosci 18:9996-10015. Medline

Piggins HD, Cutler DJ, Rusak B (1994) Effects of iontophoretically applied bombesin-like peptides on hamster suprachiasmatic nucleus neurons in vitro. Eur J Pharmacol 271:413-419. CrossRef Medline

Pitts GR, Ohta H, McMahon DG (2006) Daily rhythmicity of largeconductance $\mathrm{Ca} 2+$-activated $\mathrm{K}+$ currents in suprachiasmatic nucleus neurons. Brain Res 1071:54-62. CrossRef Medline

Roenneberg T, Kantermann T, Juda M, Vetter C, Allebrandt KV (2013) Light and the human circadian clock. Handb Exp Pharmacol 311-331. CrossRef Medline

Sakhi K, Belle MD, Gossan N, Delagrange P, Piggins HD (2013) Daily variation in the electrophysiological activity of mouse medial habenula neurons. J Physiol. Advance online publication. doi:10.1113/ jphysiol.2013.263319. CrossRef Medline

Scammell TE, Winrow CJ (2011) Orexin receptors: pharmacology and therapeutic opportunities. Annu Rev Pharmacol Toxicol 51:243-266. CrossRef Medline

Scott FF, Belle MD, Delagrange P, Piggins HD (2010) Electrophysiological effects of melatonin on mouse Per1 and non-Perl suprachiasmatic nuclei neurones in vitro. J Neuroendocrinol 22:1148-1156. CrossRef Medline

Shibata S, Moore RY (1993) Neuropeptide Y and optic chiasm stimulation affect suprachiasmatic nucleus circadian function in vitro. Brain Res 615: 95-100. CrossRef Medline

Smith RD, Inouye S, Turek FW (1989) Central administration of muscimol phase-shifts the mammalian circadian clock. J Comp Physiol A 164:805814. CrossRef Medline

Strecker GJ, Wuarin JP, Dudek FE (1997) GABAA-mediated local synaptic pathways connect neurons in the rat suprachiasmatic nucleus. J Neurophysiol 78:2217-2220. Medline 
Tsunematsu T, Kilduff TS, Boyden ES, Takahashi S, Tominaga M, Yamanaka A (2011) Acute optogenetic silencing of orexin/hypocretin neurons induces slow-wave sleep in mice. J Neurosci 31:10529-10539. CrossRef Medline

van den Pol AN, Acuna-Goycolea C (2005) Neuronal responses to hypocretin/orexin (Nishino S, Sakurai T, eds), pp 45-60. Totowa, NJ: Humana.

van den Pol AN, Obrietan K, Chen G, Belousov AB (1996) Neuropeptide Y-mediated long-term depression of excitatory activity in suprachiasmatic nucleus neurons. J Neurosci 16:5883-5895. Medline

van den Pol AN, Gao XB, Obrietan K, Kilduff TS, Belousov AB (1998) Presynaptic and postsynaptic actions and modulation of neuroendocrine neurons by a new hypothalamic peptide, hypocretin/orexin. J Neurosci 18:7962-7971. Medline

van Oosterhout F, Lucassen EA, Houben T, vanderleest HT, Antle MC, Meijer JH (2012) Amplitude of the SCN clock enhanced by the behavioral activity rhythm. PLoS One 7:e39693. CrossRef Medline

Wang TA, Yu YV, Govindaiah G, Ye X, Artinian L, Coleman TP, Sweedler JV, Cox CL, Gillette MU (2012) Circadian rhythm of redox state regulates excitability in suprachiasmatic nucleus neurons. Science 337:839-842. CrossRef Medline

Webb IC, Patton DF, Hamson DK, Mistlberger RE (2008) Neural correlates of arousal-induced circadian clock resetting: hypocretin/orexin and the intergeniculate leaflet. Eur J Neurosci 27:828-835. CrossRef Medline

Yang B, Ferguson AV (2003) Orexin-A depolarizes nucleus tractus solitarius neurons through effects on nonselective cationic and $\mathrm{K}+$ conductances. J Neurophysiol 89:2167-2175. Medline

Yoo SH, Yamazaki S, Lowrey PL, Shimomura K, Ko CH, Buhr ED, Siepka SM, Hong HK, Oh WJ, Yoo OJ, Menaker M, Takahashi JS (2004) PERIOD2::LUCIFERASE real-time reporting of circadian dynamics reveals persistent circadian oscillations in mouse peripheral tissues. Proc Natl Acad Sci U S A 101:5339-5346. CrossRef Medline

Yuste R, MacLean J, Vogelstein J, Paninski L (2011) Imaging action potentials with calcium indicators. Cold Spring Harb Protoc 2011:985-989. CrossRef Medline

Zhang S, Zeitzer JM, Yoshida Y, Wisor JP, Nishino S, Edgar DM, Mignot E (2004) Lesions of the suprachiasmatic nucleus eliminate the daily rhythm of hypocretin-1 release. Sleep 27:619-627. Medline 